Olga Tkachuk

Zakład Narodowy im. Ossolińskich

olga.tkachuk@ossolineum.pl

iD 0000-0002-3464-4838

https://doi.org/10.33077/uw.25448730.zbkh.2021.666

\title{
Archiwum Towarzystwa Naukowego im. Tarasa Szewczenki w kolekcji Zakładu Narodowego im. Ossolińskich: charakterystyka i losy zbioru
}

\author{
Archive of the Shevchenko Scientific Society in the holdings \\ of the Ossoliński National Institute : characteristics \\ and fate of the collection
}

\begin{abstract}
The Shevchenko Scientific Society is the oldest Ukrainian scientific institution that was functioning in Lviv from 1873 till 1940. After the Society's liquidation by the Soviet government, its collections were dispersed, part of the collection during World War II was relocated to Poland, where it was divided between two institutions: the National Library in Warsaw and the Ossolineum in Wrocław. The archives of the Shevchenko Scientific Society now held at the Ossolineum contain a valuable collection of documents concern the Ukrainian history of the first half of the $20^{\text {th }}$ century. Documents from the mentioned collection are of particular importance for research into the history of Ukrainian political and economic life, the literary process and the publishing movement of that period. The archive also contains important documents informing about the Polish-Ukrainian relations at that time. At the end of the $20^{\text {th }}$ and the beginning of the $21^{\text {st }}$ century parts of the Shevchenko Scientific Society collections preserved in Poland became the subject of the Polish-Ukrainian revendication negotiations. Although the idea of exchanging the Ukrainian collections transferred to Poland for the the Ossolineum collections remaining in Lviv was not realized, the problem was solved by way of copying the documents and through ensuring the access to these materials for the both parties.
\end{abstract}

Key words: The Shevchenko Scientific Society - The Ossolineum - relocation of collections in the first half of the $20^{\text {th }}$ century - revendication efforts after World War II

Słowa kluczowe: Archiwum Towarzystwa Naukowego im. T. Szewczenki - Ossolineum przemieszczanie zbiorów w 1. połowie XX w. - negocjacje rewindykacyjne po II wojnie światowej 
Towarzystwo Naukowe im. Tarasa Szewczenki (Наукове Товариство ім. Тараса Шевченка; dalej: NTSz) założone w grudniu 1873 r., to najstarsza ukraińska instytucja naukowa. Ze względu na fundamentalny wkład w tworzenie i rozwój ukraińskiej nauki i kultury na Ukrainie i w diasporze Towarzystwo doczekało się licznych badań i opracowań na temat swojej historii i zbiorów ${ }^{1}$. W polskiej literaturze przedmiotu, mimo że w Warszawie i Wrocławiu są przechowywane fragmenty archiwalnych i rękopiśmiennych zbiorów instytucji, rzadko pojawiają się publikacje na ten temat ${ }^{2}$. Wzmianki o zbiorach NTSz, które w ostatnich latach pojawiały się w polskiej przestrzeni informacyjnej i naukowej, dotyczyły głównie negocjacji związanych z ochroną i rewindykacją polskich oraz ukraińskich dóbr kultury ${ }^{3}$.

Niniejszy artykuł ma na celu przedstawienie krótkiego zarysu historii NTSz, w tym opisanie losów jego zbiorów wywiezionych w czasie II wojny światowej do Polski, oraz charakterystykę materiałów przechowywanych obecnie w kolekcji Zakładu Narodowego im. Ossolińskich (dalej: ZNiO) we Wrocławiu. Przeprowadzone badania są oparte na analizie źródeł archiwalnych oraz na analizie i krytyce literatury przedmiotu.

\section{Zarys historii NTSz}

Towarzystwo im. Szewczenki jako instytucja literacka zostało założone głównie z inicjatywy ukraińskich działaczy i naukowców z Naddnieprza ${ }^{4}$.

1 Wykaz ważniejszych publikacji do historii NTSz zob. Г.Сварник, Архівні та рукописні збірки Наукового товариства ім. Шевченка в Начіональній бібліотеці у Варшаві : Каталог-інформатор, Варшава-Львів-Нью-Йорк 2005, s. 15-17.

2 Pierwsza publikacja w języku polskim dotycząca historii NTSz, to artykuł ukraińskiego pisarza Iwana Franki w „Kurjerze Lwowskim”, zob. I. Franko, Towarzystwo imienia Szewczenki, „Kurjer Lwowski” 18 III 1892, nr 78, s. 2-3. Nowsze opracowania w języku polskim na temat zbiorów instytucji dotyczą części archiwum NTSz przechowywanej w Zakładzie Narodowym im. Ossolińskich we Wrocławiu. Zob. Tarnów - siedziba władz Ukraińskiej Republiki Ludowej. Prezentacja archiwaliów ukraińskich ze zbiorów Zakładu Narodowego im. Ossolińskich (wystawa), oprac. A. Warżel, O. Medownikow, I. Lipko Tarnów 2003; I. Sribnyak, Historia utrwalona w dokumentach. Źródtowe znaczenie zebrań archiwalnych Ossolineum dla rekonstrukcji działalności Rządu Ukraińskiej Republiki Ludowej na Emigracji (na przykładzie kolekcji 22/53), „Czasopismo Zakładu Narodowego imienia Ossolińskich” 2018, z. 29, s. 155-173.

3 Zob. m.in.: B. Bieńkowska, Działalność „,Międzyrządowej Komisji Polsko-Ukraińskiej do spraw ochrony i zwrotu dóbr kultury utraconych i bezprawnie przemieszczonych podczas II wojny światowej" w zakresie bibliotek (1996-1997), „Z Badań nad Polskimi Księgozbiorami Historycznymi” 1999, z. 19, s. 153-158; Odpowiedź podsekretarza stanu w Ministerstwie Kultury i Dziedzictwa Narodowego - z upoważnienia ministra - na interpelację nr 3320 w sprawie Zakladu Narodowego im. Ossolińnkich we Lwowie, 3 VII 2006, [online] http://orka2.sejm.gov.pl/IZ5.nsf/main/24C59E16 [dostęp 2.05.2021]; Odpowiedź podsekretarza stanu w Ministerstwie Kultury i Dziedzictwa Narodowego - z upoważnienia ministra - na interpelację $\mathrm{nr} 10390 \mathrm{w}$ sprawie odzyskania polskich pamiątek kultury zagarniętych podczas II wojny światowej, 28 VII 2009, [online] http://orka2.sejm.gov.pl/IZ6.nsf/main/4057E3C6 [dostęp 2.05.2021] i in.

4 Do założenia Towarzystwa organizacyjnie i finansowo przyczynili się przede wszystkim Ołeksandr Konyski, pisarz i publicysta, Dmytro Pylczykiw, pedagog i działacz społeczny, członek Bractwa 
Na siedzibę Towarzystwa został jednak wybrany Lwów, gdyż na Ukrainie Naddnieprzańskiej należącej wówczas do Imperium Rosyjskiego od 1863 r. obowiązywał Cyrkularz wałujewski, który zabraniał publikacji w języku ukraińskim z wyjątkiem literatury pięknej ${ }^{5}$. W celu realizacji swojego głównego zadania - „спомагати розвій малоруської словесности” - Towarzystwo zakupiło w 1874 r. drukarnię, w której do 1892 r. zostało wydrukowanych się około 50 pozycji ${ }^{7}$.

Od 1892 r. instytucja - jako Towarzystwo Naukowe im. T. Szewczenki nieformalnie pełniła funkcję ukraińskiej Akademii Nauk ${ }^{8}$. Zgodnie z nowym Statutem uchwalonym 13 III 1892 r., główny cel instytucji polegał na ,pielęgnowaniu i rozwijaniu nauki w języku ojczystym” poprzez ,badania naukowe [...], odczyty, rozprawy i dyskusje naukowe; zjazdy uczonych, literatów i artystów [...]"9. Na wzór ówczesnych zachodnioeuropejskich instytucji akademickich NTSz zostało podzielone na trzy sekcje: historyczno-filozoficzną (prowadzoną przez Mychajła Hruszewskiego), filologiczną (prowadzoną przez Iwana Frankę) oraz matematyczno-przyrodniczo-lekarską (prowadzoną przez Wołodymyra Łewyckiego), w ramach których dodatkowo funkcjonowały różne komisje. W 1892 r. NTSz zapoczątkowało wydawnictwo seryjne pt. ,Записки Наукового Товариства імені Шевченка"10, od 1900 r. wydawało Kronikę ${ }^{11}$, w której publikowano sprawozdania z działalności Towarzystwa. Oprócz tego,

Cyryla i Metodego, Mychajło Żuczenko, prawnik i działacz społeczny, ks. Stepan Kaczała, poseł na Sejm Krajowy Galicji i do austriackiej Rady Państwa, Omelan Ogonowskyj, filolog, profesor języka ruskiego i literatury na Uniwersytecie Lwowskim, Jełyzaweta Miłoradowicz ze Skoropadskich, znana działaczka społeczna i mecenaska, która ofiarowała na założenie Towarzystwa największą kwotę składającą według różnych źródeł z 20000 koron austriackich, 9000 lub 10000 guldenów, 8000 lub 12000 rubli. Zob. I. Петренко, Слизавета Милорадович (1832-1890) в украӥнському суспільно-політичному русі, Полтава 2013, s. 105; I. Franko, Towarzystwo imienia Szewczenki..., s. 2. Dla porównania, rozmiar wkładu finansowego O. Konyskiego stanowił 1000 rubli, zob. М.Г[рушевський], Олександер Кониський, „Хроніка українсько-руського НТШ у Львові” 1901, вип. 1, ч. 5, s. 23.

5 Więcej na ten temat zob. S. Plokhy, Kwestia rosyjska. Jak budowano naród i imperium, przekład Ł. Witczak, Kraków 2019, s. 171-174.

6 „wspomagać rozwój literatury małoruskiej”, cyt. za К. Студинський, До історії взаємин Галичини з Украӥною в роках 1860-1873, [w:] Україна. Науковий двомісячник украӥнознавства. Кн. 2, Київ 1928, s. 39. Tutaj i dalej thumaczenia autorki.

7 Wykaz wydań NTSz zob. Періодичні та серійні видання Наукового товариства імені Шевченка (1885-1939). Анотований покажчик, Львів 1991.

8 Pomysł, że zreformowane Towarzystwo powinno stać się początkiem przyszłej ukraińskiej Akademii Nauk wyraził jeszcze w 1889 r. jeden z fundatorów NTSz O. Konyskyj, zob. О. Кониський, До реформи Товариства ім. Т. Шевченка, „Правда” 1889, т. 2, s. 307.

9 I. Franko, Towarzystwo imienia Szewczenki..., s. 2-3.

10 Seria wydawnicza kontynuowana jest do dziś we Lwowie; między 1947 a 1990 r. ze względu na sytuację polityczną czasopismo wychodziło na emigracji - w Europie, Ameryce i Kanadzie.

11 Czasopismo wychodziło pod różnymi tytułami: „Хроніка українсько-руського Наукового товариства імені Шевченка у Львові” (1900-1906), „Хроніка Наукового товариства імені Шевченка у Львові” (1906-1939). 
poszczególne sekcje i komisje przy NTSz wydawały publikacje zwarte i ciągłe, w których prezentowały wyniki swojej działalności i badań naukowych ${ }^{12}$.

Zgodnie z celami NTSz określonymi w Statucie z 1892 r., którymi są ,gromadzenie i konserwowanie wszelkich pamiątek, starożytności i przedmiotów naukowych Rusi-Ukrainy"13, przy Towarzystwie, oprócz wspomnianej wyżej drukarni, założone zostały Biblioteka ${ }^{14}$ oraz Muzeum ${ }^{15}$.

\section{Losy zbiorów NTSz wywiezionych do Polski}

Losy NTSz, jak i wszystkich innych instytucji bibliotecznych, naukowych i kulturalnych zmieniła II wojna światowa oraz okupacja Lwowa przez władze niemieckie i radzieckie. Podczas pierwszej okupacji radzieckiej, zgodnie z Uchwałą Rady Komisarzy Ludowych USRR z 2 I 1940 r., biblioteka NTSz wraz z księgozbiorami Ossolineum i Narodnego Domu została włączona do struktury nowo utworzonej we Lwowie filii Biblioteki Akademii nauk USRR $^{16}$. Muzeum zostało zlikwidowane, a jego zbiory rozproszone między różnymi instytucjami muzealnymi ${ }^{17}$. Drukarnię NTSz razem z wydawnictwem Ossolineum przekazano Akademii Nauk USRR ${ }^{18}$. 14 I 1940 r. na posiedzeniu nadzwyczajnym NTSz ,podjęto decyzję” o samorozwiązaniu instytucji i przekazaniu jej mienia Akademii Nauk USRR ${ }^{19}$.

12 Zob. Г. Сварник, Архівні та рукописні збірки..., s. 8-9.

13 I. Franko, Towarzystwo imienia Szewczenki..., s. 3.

14 Szerzej o historii biblioteki NTSz zob. Г. Сварник, Бібліотека наукового товариства ім. Шевченка у Львові, [w:] Енциклопедія „Наукове товариство імені Шевченка” [online]

http://encyclopedia.com.ua/search_articles.php?id=277 [dostęp 10.05.2021].

15 Więcej na temat Muzeum NTS̄z, jego historii i zbiorów zob. В. Кушнір, Музей Наукового товариства ім. Шевченка у Львові: від заснування до створення першої загальнодоступної експозииії, „Народознавчі зошити” 2012, вип. 5, s. 824-832; О. Сілецька, Засади діяльності Музею Наукового Товариства ім. Т. Шевченка у Львові, „Записки НТШ” 2001, т. 242, s. 595-604.

16 Науковий архів Президії НАН України (Archiwum Naukowe Prezydium Narodowej Akademii Nauk Ukrainy: dalej ANPNANU), zespół 251, op. 1, sygn. 79, k. 1; opublikowano w: Iсторія Національної Академї наук України: 1938-1941 : док. і матеріали, упоряд. В.А. Кучмаренко, Т.П. Папакіна, Л.І. Стрельська та ін., Київ 2003, s. 239; Львівська національна наукова бібліотека України імені В. Стефаника: переміщення і втрати фондів. Т. 1: 1939-1945, Львів 2010, s. 22-23.

17 ANPNANU, zespół 251, op. 1, sygn. 79, k. 1; opublikowano w: Історія Національної Академї наук Украӥни..., s. 239; Львівська національна наукова бібліотека Украӥни імені В. Стефаника..., s. 22-23.

18 ANPNANU, zespół 251, op. 1, sygn. 79, k. 2; opublikowano w: Львівська національна наукова бібліотека України імені В. Стефаника..., s. 23.

19 Центральний державний історичний архів України у Львові (Centralne Państwowe Archiwum Historyczne Ukrainy we Lwowie; dalej: CPAHU we Lwowie), zespół 309, op. 1, sygn. 31, k. 93-96; opublikowano w: Львівська національна наукова бібліотека Украӥни імені В. Стефаника..., s. 24-27. 
Podczas okupacji niemieckiej w listopadzie $1941 \mathrm{r}$. Biblioteka NTSz została włączona do struktury Staatsbibliothek Lemberg ${ }^{20}$. Wiosną 1944 r. w związku ze zbliżającym się do Lwowa frontem władze niemieckie postanowiły ewakuować na Zachód - najpierw do Krakowa, do Biblioteki Jagiellońskiej, a potem w głąb Rzeszy - wszystkie unikatowe zbiory ${ }^{21}$. Wbrew instrukcjom, nakazującym przede wszystkim ewakuację niemieckiej literatury fachowej i księgozbiorów podręcznych czytelni głównej, do transportów ewakuacyjnych trafily fragmenty zbiorów z różnych Działów Staatsbibliothek ${ }^{22}$, w tym część archiwum $\mathrm{NTSz}^{23}$.

Porzucone w trakcie ewakuacji w miejscowości Adelin (niem. Adelsdorf; obecnie Zagrodno) na Dolnym Śląsku, po zakończeniu działań wojennych zbiory te zostały odnalezione przez polskich bibliotekarzy. Stan zachowania materiałów był „,okropny” 24 - rozbite skrzynie nosiły ślady rabunku, ,wyrzucone książki i rękopisy walały się na betonowej posadce stajni, leżały na dziedzińcu folwarcznym, częściowo w sąsiednich budynkach" ${ }^{\text {"25 }}$. Wśród odnalezionych materiałów Bohdan Horodyski, pracownik Biblioteki Narodowej, wymienia m.in. skrzynie oznaczone sygnaturami Biblioteki Uniwersyteckiej we Lwowie (56 skrzyń), Ossolineum (40 skrzyń) oraz Towarzystwa Szewczenki (osiem skrzyń) ${ }^{26}$.

Po wywiezieniu zbiorów do Warszawy do Biblioteki Narodowej (dalej: BN) jeszcze 20 skrzyń wywiezionych wcześniej z Adelina, żeby je jak najszybciej zabezpieczyć, pozostało w Kępnie, w magazynie spółdzielni „Rolnik”27. Ponadto

20 Pod koniec listopada 1941 r. na strukturę Staatsbibliothek Lemberg składało się pięć działów. Biblioteka NTSz należała do III Działu, Ossolineum wraz z Biblioteką Baworowskich tworzyły II Dział Biblioteki, zob. ZNiO, Dział Rękopisów, sygn. 17129 II, t. 1, k. 50.

21 M. Matwijów, Ewakuacja zbiorów polskich ze Lwowa w 1944 r., „Rocznik Lwowski” 1995-1996, s. 36, 41-42.

22 Sprawozdanie Alexandra Himpla dla Gtównego Zarzadu Bibliotek z zabezpieczenia zbiorów specjalnych Biblioteki Państwowej we Lwowie z 18 IV 1944 r., [w:] Biblioteki naukowe w Generalnym Gubernatorstwie w latach 1939-1945. Wybór dokumentów źródtowych, wybór i oprac. A. Mężyński przy współpracy H. Łaskarzewskiej, Warszawa 2003, s. 197-198; Р. Дзюбан, Втрати культурних цінностей з II відdiлy Staatsbibliothek Lemberg в 1944 p., „Записки Львівської Національної Наукової Бібліотеки України ім. В. Стефаника” 2008, № 1, s. 388.

23 Dokumenty źródłowe podają różną ilość skrzyń z materiałami NTSz wywiezionych do Krakowa. Wiadomo, że do 13 z nich zostały spakowane archiwa Ukraińskiej Armii Halickiej, Ukraińskich Strzelców Siczowych oraz rodziny Baczyńskich, zob. Державний архів Львівської області (Archiwum Państwowe we Lwowie), zespół R-49, op. 1, sygn. 4, k. 18, 24; zob. też: Г. Сварник, Архівні та рукописні збірки ..., s. 20-21; Я.Дашкевич, Як нищили незнищенне, „Дзвін” 1991, № 8, s. 114-119.

24 Tego określenia w celu opisania stanu zachowania zbiorów używa historyk Stefana Inglot w liście do Mieczysława Gębarowicza, zob. ZNiO, Dział Rękopisów, sygn. 16391, s. 269-270; opublikowano w: M. Matwijów, Walka o lwowskie dobra kultury w latach 1945-1948, Wrocław 1996, s. 204.

25 [Sprawozdanie Bohdana Horodyskiego, bibliotekarza Biblioteki Narodowej z 25 X 1945 r.], [w:] Львівська наиіональна наукова бібліотека України імені В. Стефаника..., s. 351.

26 Tamże, s. 353.

27 NZiO, Dział Rekopisów, nr akc. 70/88/1, [Sprawozdania Bohdana Horodyskiego z 12 IX i 25 X 1945 r.]; opublikowano w: Львівська національна наукова бібліотека України імені В. Стефаника..., s. 339-340; tamże, s. 351-354. 
150 wiązek książek zapomnianych w trakcje pakowania transportu do Warszawy, pozostało w piwnicy Biblioteki Uniwersyteckiej we Wrocławiu ${ }^{28}$. Materiały te również zostały w najbliższym czasie dostarczone do Warszawy ${ }^{29}$, gdzie po segregacji częściowo były zwrócone do Biblioteki Uniwersyteckiej we Wrocławiu ${ }^{30}$.

W BN dokumenty z archiwum NTSz zostały pobieżnie posegregowane i umieszczone w dziesięciu skrzyniach, gdzie ok. 40 lat czekały na swoje opracowanie. Materiały te w 1982 r. odkrył historyk Eugeniusz Misiła i dzięki jego staraniom zaczęło się ich porządkowanie i mikrofilmowanie ${ }^{31}$. W $1990 \mathrm{r}$. rozpoczął się projekt badawczy w celu wyodrębnienia, opracowania, opisania i zmikrofilmowania dokumentów i rękopisów z archiwum NTSz w zbiorach BN. Głównym wynikiem i zwieńczeniem wieloletniej pracy, którą wspierało wiele osób i instytucji, stal się katalog-informator Архівні та рукописні збірки Наукового Товариства ім. Шевченка в Національній Бібліотещі у Варшаві, przygotowany i wydany w 2005 r. przez ukraińską badaczkę i znawczynię dziejów i zbiorów NTSz Halinę Swarnyk ${ }^{32}$.

Oprócz dokumentów archiwalnych, Katalog-informator $\mathrm{H}$. Swarnyk rejestruje nieliczne książki i broszury z Biblioteki NTSz wydane w latach 1829-1927, które były dokładane do skrzyń z rękopisami, żeby je wypełnić ${ }^{33}$. W ten sposób do $\mathrm{BN}$ w Warszawie trafiły również stare druki ze zbiorów Biblioteki NTSz - 18 egzemplarzy oznaczonych pieczątką instytucji notuje Katalog druków cyrylickich $X V$-XVIII wieku Zofii Żurawińskiej i Zoi Jaroszewicz-Pieresławcew ${ }^{34}$.

Część zbiorów z archiwum NTSz, odnalezionych w Adelinie, trafiła również do Zakładu Narodowego im. Ossolińskich we Wrocławiu (o tym - dalej). Na Ukrainie zgodnie z decyzjami władz radzieckich, muzealne i biblioteczne zbiory NTSz zostały rozproszone między różnymi instytucjami w kraju, część została wywieziona do Moskwy ${ }^{35}$. Po II wojnie światowej NTSz kontynuowało swoją działalność na emigracji - w Europie Zachodniej, Ameryce, Kanadzie oraz Australii. Od 1989 r. do dziś Towarzystwo Naukowe im. T. Szewczenki funkcjonuje we Lwowie.

28 [Sprawozdanie Bohdana Horodyskiego, bibliotekarza Biblioteki Narodowej z $25 X$ $1945 r$ r. ..., s. 353.

29 Г.Сварник, Архівні та рукописні збірки..., s. 22.

30 [Sprawozdanie Bohdana Horodyskiego, bibliotekarza Biblioteki Narodowej z 25 X 1945 r.]..., s. 354.

31 Więcej o działaniach E. Misiły na rzecz opracowania archiwum NTSz przechowywanego w zbiorach BN zob. Є. Місило, Українські цінності у варшавському сховищі, [w:] Слідами пам'яті. Літописний календар. Т. 1, Варшава 1996, s. 109-112.

32 Г. Сварник, Архівні та рукописні збірки...

33 Tamże, s. 144.

34 Zob. Katalog druków cyrylickich XV-XVIII wieku w zbiorach Biblioteki Narodowej, oprac. Z. Żurawińska, Z. Jaroszewicz-Pieresławcew, Warszawa 2004 (poz. kat. 54c, 102b, 110b, 112, 118, 174b, 177c, 207b, 257, 296b, 299, 304, 307, 322, 336, 369, 380, 381).

35 O aktualnej lokalizacji rozproszonych zbiorów NTSz zob. Г. Сварник, Архівні та рукописні збірки..., s. 13-17. 


\section{Polsko-ukraińskie negocjacje rewindykacyjne w sprawie archiwum NTSz}

Część archiwum NTSz wywieziona ze Lwowa i przechowywana obecnie w BN w Warszawie oraz w Ossolineum we Wrocławiu, niejednokrotnie była „kością niezgody” we współczesnych relacjach polsko-ukraińskich. Chociaż spory między dwoma stronami o zwrot dóbr kultury przemieszczonych lub pozostawionych w czasie II wojny światowej zaczęły się znacznie wcześniej, już w 1945 r. Dotyczyły one głównie kolekcji Ossolineum, większość której po wojnie pozostała we Lwowie ${ }^{36}$, ale również ukrainików wywiezionych do Polski jako część ossolińskich zbiorów ${ }^{37}$.

Na skutek porozumienia między Rządem Rzeczypospolitej Polskiej a Rządem Ukrainy 25 VI 1996 r. została powołana Międzyrządowa Komisja Polsko-Ukraińska do spraw ochrony i zwrotu dóbr kultury utraconych i bezprawnie przemieszczonych podczas II wojny światowej ${ }^{38}$. Pierwsze posiedzenie Komisji, które odbyło się w Kijowie 12-15 XII 1996 r., miało charakter wstępny. Na kolejnym spotkaniu, które miało miejsce we Lwowie w dn. 13-16 V 1997 r., została powołana osobna polsko-ukraińska grupa ekspertów do uregulowania spraw byłej Biblioteki Ossolineum we Lwowie. Na posiedzeniu strona ukraińska m.in. podniosła problem rozproszonych w polskich instytucjach muzealnych i bibliotecznych zbiorów Kapituły Greckokatolickiej w Przemyślu ${ }^{39}$. Na konferencji prasowej po zakończeniu spotkania członkowie Komisji z Ukrainy po raz pierwszy poruszyli temat ,poniewierania fragmentów archiwum Towarzystwa Naukowego im. Szewczenki w Bibliotece Narodowej"40.

W październiku 2002 r. strona ukraińska złożyła wniosek rewindykacyjny dotyczący fragmentu archiwum NTSz przechowywanego w $\mathrm{BN}^{41}$. Podczas trzeciego posiedzenia zespołu ekspertów ds. Ossolineum w 2003 r. we Wrocławiu strona polska złożyła propozycję wymiany - po opracowaniu i zmikrofilmowaniu - archiwum własnego Ossolineum na materiały archiwum NTSz. Podczas szóstego spotkania Komisji w Olsztynie w dn. 13-16 VI 2015 r. ${ }^{42}$ pro-

36 Więcej na ten temat zob. M. Matwijów, Walka o lwowskie dobra kultury...

37 Pierwszy wniosek o zwrot materiałów rękopiśmiennych dotyczących historii Ukrainy, wywiezionych do Polski wraz ze zbiorami Ossolineum i Biblioteki Baworowskich, złożył 6 IX 1945 r. Iwan Krypiakewycz, kierownik Lwowskiej filii Instytutu historii Ukrainy. Zob. Національна бібліотека України ім. В. Вернадського (Biblioteka Narodowa Ukrainy im. W. Wiernadskiego), Archiwum, op. 1, sygn. 657, k. 117; opublikowano w: Львівська національна наукова бібліотека України імені В. Стефаника..., s. 337.

38 B. Bieńkowska, Działalność „Międzyrządowej Komisji Polsko-Ukraińskiej...

39 Tamże, s. 156.

40 Tamże.

41 Zob. Odpowiedź podsekretarza stanu w Ministerstwie Kultury i Dziedzictwa Narodowego...

42 Obrady Międzyrządowej Komisji Polsko-Ukraińskiej z 17 VI 2015 r., [online] http://www. 
pozycja ta została wpisana do protokołu. Polegała ona na wymianie do końca 2016 r. materiałów archiwum NTSz z BN w Warszawie i ZNiO we Wrocławiu na archiwum Ossolineum przechowywany w zbiorach Lwowskiej Narodowej Naukowej Biblioteki Ukrainy im. W. Stefanyka (dalej: LNNBU) ${ }^{43}$. Ze względu na sprzeciw środowisk naukowych i kulturowych strona ukraińska ostatecznie wycofała się z tych ustaleń ${ }^{44}$. Więc obecnie archiwum lwowskiego Ossolineum pozostaje w Dziale Rękopisów LNNBU im. W. Stefanyka. W ramach współpracy z $\mathrm{ZNiO}$ większa część tych materiałów została opracowana, zeskanowana i udostępniona $\mathrm{w}$ sieci ${ }^{45}$.

Dokumenty NTSz ze zbiorów Ossolineum i BN w Warszawie, dzięki wsparciu Ministerstwa Nauki i Szkolnictwa Wyższego RP, zostały zeskanowane i przekazane lwowskiej bibliotece. Uroczystość przekazania kopii cyfrowych odbyła się w LNNBU im. W. Stefanyka 3 X 2019 r. ${ }^{46}$

Po 2019 r. w Dziale Rękopisów ZNiO kontynuowane są prace związane z opracowaniem i udostępnianiem materiałów z archiwum NTSz - w 2020 r. zostały one zaprezentowane w wersji elektronicznej na stronie Dolnośląskiej Biblioteki Cyfrowej ${ }^{47}$. W tymże roku autorka niniejszej publikacji rozpoczęła pracę nad przygotowaniem przewodnika po archiwum NTSz w zbiorach Ossolineum. Na podstawie przeprowadzonych badań w niniejszym artykule zostanie przedstawiona ogólna charakterystyka zawartości zbioru.

\section{Fragment archiwum NTSz w zbiorach $\mathrm{ZNiO}$}

Dokładna data, jak również okoliczności, w jakich dokumenty ze zbiorów NTSz wpłynęły do Ossolineum, pozostają nieustalone. Do Działu Rękopisów, w którym przechowywane są do dziś, materiały te zostały przekazane w 1953 r. z Magazynu Głównego ZNiO, o czym świadczą zapisy w księdze akcesyjnej. Dokumenty zostały objęte akcesją i umieszczone w 72 teczkach o sygn. 20/53, 21/53/1-6, 22/53/1-26. Po raz pierwszy część zbioru

mkidn.gov.pl/pages/posts/obrady-miedzyrzadowej-komisji-polsko-ukrainskiej-5577.php [dostęp 30.04.2021].

43 P. Gliński, Odpowiedź na interpelację nr 15081 w sprawie odzyskiwania dziet sztuki $i$ zbiorów polskiego malarstwa, [online] http://www.sejm.gov.pl/sejm8.nsf/InterpelacjaTresc. xsp?key=71974A4E [dostęp 30.04.2021].

44 Г. Сварник, Чи повернуться в Украӥну архіви Наукового товариства імені Шевченка?, „Дзеркало Тижня” 22 X 2016, № 38/39, [online] http://gazeta.dt.ua/article/print/personalities/chi-povernutsya-v-ukrayinu-arhivi-naukovogotovaristva-imeni-shevchenka-_html. [dostęp 10.05.2021].

45 Zob. [online] http://bazy.oss.wroc.pl/kzc/ [dostęp 30.04.2021].

46 Wcześniej zmikrofilmowane kopie znacznej części archiwum NTSz zostały przekazane z BN do CPAHU we Lwowie, zob. Г. Сварник, Архівні та рукописні збірки..., s. 26.

47 Zob. [online] https://www.dbc.wroc.pl/dlibra/results?q=archiwum+szewczenki\&action=SimpleSearchAction\&type $=-6 \& p=0$ [dostęp 30.04.2021] . 
Archiwum Towarzystwa Naukowego im. Tarasa Szewczenki w kolekcji...

archiwalnego NTSz przechowywana w Ossolineum, została zaprezentowana publiczności na wystawie pod tytułem Tarnów - siedzibą władz Ukraińskiej Republiki Ludowej, która odbyła się w Muzeum Okręgowym w Tarnowie w sierpniu - wrześniu 2003 r. Patronat honorowy nad wystawą obją ówczesny konsul generalny Ukrainy w Krakowie Ołeksandr Medownikow, który właściwie na początku XXI w. odkrył w zbiorach ZNiO dokumenty z ukraińskiego archiwum. Jako kurator i autor publikacji towarzyszącej wystawie wystąpił tarnowski historyk Andrzej Warżel. Broszura zawiera krótki wstęp oraz ogólny spis zawartości części materiałów z archiwum NTSz, przedstawionych na wystawie ${ }^{48}$. Po prezentacji zbiorów dla naukowców i szerokiej publiczności rozpoczęły się prace związane z ich uporządkowaniem i naukowym opracowaniem. Wielka zasługa w tym ukraińskich naukowców, przede wszystkim wspomnianej już Haliny Swarnyk oraz Lidii Snicarczuk z LNNBU im. W. Stefanyka, a także historyków Ihora Sribniaka i Witalija Telwaka, którzy opublikowali szereg artykułów na temat zbiorów NTSz z kolekcji Ossolineum ${ }^{49}$. W uporządkowaniu dokumentów uczestniczył także prof. Rościsław Żerelik z Uniwersytetu Wrocławskiego.

48 Tarnów - siedziba władz...

49 Zob. m.in.: Л. Сніцарчук, „Тарнів. Еміграиія. 1921 рік”: Щоденникові записи журналіста Назара Гнатюка, „Збірник Праць Науково-дослідного Інституту Пресознавства” 2014, вип. 4, s. 559-573; tejże, Назар Гнатюк: „Бути журналістами в тяжкий для пресової праиі час” (1917-1921), „Образ” 2017, вип. 3, s. 78-87; tejże, „Організація дійсної і доиільної пропаганди за кордоном”: міністерство преси $і$ пропаганди УНР у 1921 р., „Вісник Львівського Університету. Серія Журналістика” 2015, вип. 40, s. 144-155; tejże, „Назвете нашу уперту праџю корисною”: Вибране з листів Василя Короліва-Старого до Олександра Ковалевського (1919-1921 рр.), [w:] Українська періодика : історія і сучасність : матеріали 11 Всеукр. наук.-теорет. конф., Львів 2013, s. 581-591; tejże, Архівні документи до історії Української народної партії (1918-1921 рр.) у відділі рукописів Національного закладу імені Оссолінських, [w:] Рукописна та книжкова спадщина України. Вип. 25, Київ 2020, s. 39-51; teјże, Джерела до історії украӥнської журналістики у фондах рукописів Національного закладу імені Оссолінських, „Збірник Праць Науково-дослідного Інституту Пресознавства” 2019, вип. 9 (27), s. 50-63; I. Sribnyak, Historia utrwalona $w$ dokumentach..., s. 155-173; tegoż, Генерал В. Павленко vs міністра О. Ковалевського: Спроба реконструкиії конфлікту між двома членами уряду УНР в екзилі (за матеріалами ЗНіО та ЦДАВО України), „Емінак” 2018, № 2 (22), s. 40-45; М. Палієнко, І. Срібняк, Інформаиійно-джерельний потенціал архівних збірок Національної установи імені Оссолінських у Вроилаві з історії УНР (колекиія 22/53), „Етнічна Історія Народів Європи" 2018, вип. 54, s. 127-140; tegoż, Республіка Польща і Украӥнська Народна Республіка у боротьбі з більшовизмом у 1921 р. Організаиійно-агентурна діяльність Партизансько-Повстанського штабу при головній команді Військ УНР (за матеріалами $3 \mathrm{HiO}$ i $5 H$ ), [w:] Rozpad imperiów. Ksztaltowanie powojennego tadu w Europie Środkowo-Wschodniej w latach 1918-1923, red. M. Gibiec, G. Hryciuk, R. Klementowski, Wrocław-Warszawa 2020, s. 492-507; В.В. Тельвак, В.П. Тельвак, ,, Страшенно важно зберігати в се время люте живий партійний осередок”: листи Михайла Грушевського з бібліотеки Національного інституту ім. Оссолінських, „Український Історичний Журнал” 2019, № 3, s. 166-182 oraz inne. 


\section{Charakterystyka zasobu}

Zasób archiwalny NTSz przechowywany obecnie w zbiorach Ossolineum zawiera fragmenty kilku archiwów, m.in.: 1. Archiwum spółdzielni wydawniсzеј „Червона Калина” (dalej: „Červona Kalina”) ${ }^{50} ; 2$. Archiwum Sztabu Partyzancko-Powstańczego (dalej: SPP) przy Głównej Komendzie Armii URL; 3. Archiwum Ołeksandra Kowałewskiego; 4. Archiwum Ostapa (Stanisława) Łuckiego, a także fragmenty i poszczególne dokumenty z innych zbiorów. Materiały te są głównie związane z dziejami ukraińskiego ruchu wyzwoleńczego lat 1917-1921 oraz z działalnością Centrum Państwowego Ukraińskiej Republiki Ludowej (dalej: URL) ${ }^{51}$ na wychodźstwie.

\subsection{Archiwum spółdzielni wydawniczej Červona Kalina}

Pierwszą grupę w omawianym zasobie tworzą materiały z archiwum spółdzielni wydawniczej „Červona Kalina” założonej w 1921 r. we Lwowie przez byłych żołnierzy Legionu Ukraińskich Strzelców Siczowych (dalej: USS) ${ }^{52}$ oraz Ukraińskiej Armii Halickiej (dalej: UHA) ${ }^{53}$ w celu gromadzenia i upowszechnienia materiałów związanych z walką o niepodległość Ukrainy w latach 1917-1921 ${ }^{54}$. W pierwszym okresie swojej działalności, czyli do $1939 \mathrm{r}^{55}$, oficyna wydawała teksty publicystyczne, naukowe i literackie, czasopisma, kalendarze, albumy, broszury, druki ulotne i inne. Główne wydawnictwa seryjne spółki to „Історичний календар-альманах Червоної Калини” (dalej: „IKAČK”; 1922-1939) oraz „Літопис Червоної Калини” (dalej: „LČKК”; 1929-1939), w których publikowano relacje, wspomnienia, fragmenty dzienników wojennych oraz utwory literackie uczestników ukraińskiego ruchu wyzwoleńczego lat 1917-1921.

Największa cześć archiwum spółdzielni wydawniczej „Červona Kalina” jest przechowywana obecnie w Centralnym Państwowym Archiwum Historycznym

50 Dalej w tekście podaję formę transliterowaną zgodnie z normą ISO 9:2000.

51 Zbiorczym terminem „Centrum Państwowe” określano system naczelnych władz URL działających na emigracji w Tarnowie. Chodzi o Dyrektoriat pełniący rolę kolegialnej, a później jednoosobowej, głowy państwa, Radę Ministrów i Radę Republiki URL, zob. J.J. Bruski, Petlurowcy. Centrum Państwowe Ukraińskiej Republiki Ludowej na wychodźstwie (1919-1924), Kraków 2000, s. 14.

52 USS - ukraińska formacja wojskowa w składzie Armii Austro-Węgier. Więcej o formacji w języku polskim zob. M.B. Kozubel, Ukraińscy Strzelcy Siczowi 1914-1920, Oświęcim 2015.

53 UHA - siły zbrojne Zachodnioukraińskiej Republiki Ludowej. Więcej o formacji w języku polskim zob. M. Krotofil, Ukraińska Armia Halicka 1918-1920, Toruń 2003.

54 Szerzej o spółce wydawniczej „Červona Kalina” i jej wydaniach zob. В. Передирій, Видання ,Червоної Калини” (1922-1939), Львів 2004.

55 Po przerwie wydawnictwo wznowiło działalność w Nowym Jorku w 1949 r., zob. К. Науменко, Червона Калина, [w:] Енциклопедія історії Украӥни : у 10 m. Т. 10, редкол. В.А. Смолій (голова) та ін., Київ 2013, s. 491-492. 
Ukrainy (Центральний державний історичний архів України у Львові; dalej: CPAHU) we Lwowie (zespół 316), nieliczne dokumenty w trakcie przemieszczania się zbiorów podczas II wojny światowej trafiły do BN w Warszawie. W Dziale Rękopisów ZNiO materiały z analizowanego archiwum są zgromadzone w 34 teczkach ${ }^{56}$. Zbiór zawiera autografy dzieł różnych autorów wysyłane do redakcji „Červonej Kaliny” w latach 20. i 30. XX w., korespondencję oraz inne materiały redakcyjne wydawnictwa. Papiery redakcyjne „Červonej Kaliny”, przynajmniej ich część, do biblioteki NTSz trafiły jako depozyt w latach 1939-1940 wraz z innymi zbiorami rękopiśmiennymi przekazywanymi w tym okresie do instytucji ${ }^{57}$.

\subsubsection{Autografy wspomnień, relacji, pamiętników, dzienników}

Najcenniejszą część omawianego zasobu z archiwum NTSz niewątpliwie stanowią autografy tekstów. Ze względu na profil wydawnictwa, które wielokrotnie apelowało do byłych ukraińskich żołnierzy o przesyłanie materiałów związanych z walkami wyzwoleńczymi ${ }^{58}$, wśród tekstów przeważają wspomnienia, relacje, pamiętniki oraz dzienniki wojenne z opisami tych wydarzeń. Do wydawnictwa trafiały teksty autorstwa zarówno dowódców ukraińskich formacji wojskowych, jak i zwykłych żołnierzy, których imiona często pozostają nieznane.

W analizowanym zbiorze znajdują się m.in. wspomnienia generała Armii URL Wsewołoda Petriwa ${ }^{59}$ związane $\mathrm{z}$ jego działalnością jako organizatora i kierownika Szkoły Wojskowej w Żytomierzu $(1918-1919)^{60}$; relacje pułkownika Mychajła Palija-Sydorianskiego ${ }^{61}$, w których opisany został epizod z jego pobytu w obozie dla internowanych żołnierzy w Strzałkowie ${ }^{62}$; wspomnienia porucznika Wołodymyra Gałana ${ }^{63}$ dotyczące życia codziennego ukraińskich żołnierzy w Armii Austro-Węgier (1914) oraz UHA (1919)64, relacje generała Mychajła Krata, szefa Sztabu Zaporoskiej Grupy Armii URL, pt. „Лицарі

56 Sygn. 20/53, 21/53/1-3, 21/53/2/1-8, 21/53/3/1-3, 21/53/4/1-4, 21/53/5/1-5, 21/53/6/1-2, 21/53/18, 21/53/20, 21/53/21, 21/53/22, 21/53/23, 21/53/24/1-6, 21/53/25/1-4, 21/53/26/1-2.

57 LNNBU im. W. Stefanyka, Dział Rekopisów, zespół 9, sygn. 1494, k. 1-8; opublikowano: Рукописні збірки, які потрапили як депозит до відділу рукописів Бібліотеки НТШ у 1939-1940 pp., [w:] Львівська національна наукова бібліотека Украӥни імені В. Стефаника..., s. 181-187 (poz. 120).

58 Zob. В. Передирій, Видання „Червоної Калини”..., s. 18-19, 48.

59 Więcej o nim zob. А. Буравченков, Петрів Всеволод Миколайович, [w:] Енииклопедія історії України : 10 m. Т. 8, редкол. В.А. Смолій (голова) та ін., Київ 2011, s. 185.

60 Sygn. 21/53/2/1, k. 124-126; opublikowano w: Історичний календар-альманах Червоної Калини на 1930 рік, Львів 1929, s. [3], [5].

61 Я. Тинченко, Офіцерський корпус Армії Украӥнської Народної Республіки (1917-1921). Кн. 1, Київ 2007, s. 396-397.

62 Fragment bez początku, podpisany inicjałami M.K. [sygn. 21/53/2/1, k. 119-121].

63 Галан Володимир, [w:] Енциклопедія українознавства. Т. 2, ред. В. Кубійович, ПарижНью-Йорк 1957, s. 472.

64 Sygn. 21/53/5/2, k. 6-10. 
Залізного Хреста"65, w których autor jako bezpośredni uczestnik opisał przebieg wydarzeń tzw. I pochodu zimowego ${ }^{66}$.

W omawianym zasobie znajdują się również obszerne wspomnienia przygotowane przez autorów do publikacji, które jednak nigdy w całości nie ukazały się drukiem. Dotyczy to m.in. tekstu Wasyla Zadoiannego ${ }^{67}$, wówczas setnika Armii URL, w którym opisano przebieg ukraińskiej rewolucji 1917-1918 r. w dawnym powiecie taraszczańskim w gubernii kijowskiej ${ }^{68}$. W 1932 r. w „LČK ${ }^{{ }^{69}}$ opublikowana została jedynie część tekstu z adnotacją w tytule „Fragment z przygotowanej do druku książki «Таращанський повіт в боротьбі за самостійність України»" setnika Wołodymyra Sekundy ${ }^{72}$, w których opisał on dzieje 5. Brygady Piechoty UHA, zachowały się w kilku egzemplarzach - jeden rękopis z poprawkami redaktorskimi ${ }^{73}$ oraz dwa maszynopisy ${ }^{74}$. Autor na pewno planował publikację swojej pracy, o czym świadczy korekta redakcyjna, ale także schematy działań wojennych, które dodane zostały do tekstu w postaci ilustracji ${ }^{75}$.

Wśród autorów - uczestników ukraińskiego ruchu wyzwoleńczego - których wspomnienia często pojawiały się na stronach wydań „Červonej Kaliny”, byli znani pisarze i artyści, m.in. Oles' Babij, żołnierz UHA ${ }^{76}$, Osyp Dumin, setnik Legionu USS ${ }^{77}$, Dmytro Gonta, dowódca Pułku Czarnych Zaporożców,

65 Sygn. 21/53/2/5, k. 3-27.

66 I pochód zimowy (6 XII 1919 - 6 V 1920), operacja ofensywna oddziałów Armii URL przeciw wojskom bolszewickim i Siłom Zbrojnym Południa Rosji. Szerzej o tej kampanii w języku polskim zob. J. Legieć, Armia Ukraińskiej Republiki Ludowej w wojnie polsko-ukraińsko-bolszewickiej w 1920 r., Toruń 2003.

67 Р. Пилипчук, Задоянний Василь, [w:] Енииклопедія Сучасної Украӥни, [online] http:// esu.com.ua/search_articles.php?id=15329 [dostęp 01.05.2021].

68 Rękopis zawiera cz. 1 pt. „3 дня революції 1917 року, до загального повстання 1918 року”, zob. sygn. 21/53/1/3, IV, $214 \mathrm{k}$.

69 В. Задоянний, Наддністряниі в Таращанському повіті, „Літопис Червоної Калини” 1932 , ч. 2 , s. $6-7$.

70 „Уривок з прилагодженої до друку книжки «Таращанський повіт в боротьбі за самостійність України»".

71 В. Задоянний, Наддніпрянці в Таращанському повіті : уривок з приладженої до друку книжки : „Таращанський повіт в боротьбі за самостійність Украӥни”, „Наука і Суспільство” 2020, № 1-2, s. 45-46.

72 Сокальська (5) бригада, [w:] Енциклопедія українознавства. Т. 8, ред. В. Кубійович, Париж-Нью-Йорк 1976, s. 29-38.

73 Sygn. 21/53/2/2, k. 29-75.

74 Sygn. 21/53/2/7, k. 59-191.

75 Ilustracje posiada tylko egzemplarz rękopiśmienny, w egzemplarzach maszynopisu na miejscu ilustracji są pozostawione puste miejsca.

76 Więcej o nim zob. Бабій Олесь, [w:] Енииклопедія украӥнознавства. Т. 1, ред. В. Кубійович, Париж-Нью-Йорк 1955, s. 79.

77 Więcej o nim zob. Т. Осташко, Думін (Думин) Осип Олексійович, [w:] Енциклопедія історії України : y 10 m. Т. 2, редкол. В.А. Смолій (голова) та ін., Київ 2004, s. 494. 
setnik Armii URL ${ }^{78}$, Il'ko Kaliczak, żołnierz Legionu USS i UHA ${ }^{79}$, Iwan Zubenko, setnik Armii URL ${ }^{80} \mathrm{i}$ inni. Ich wspomnienia w formie rękopisów lub maszynopisów są prezentowane w analizowanym zbiorze ${ }^{81}$.

Wśród uczestników walk o niepodległość Ukrainy, którzy zostawili wspomnienia o tych wydarzeniach, byli przyszli duchowni i działacze religijni. W archiwum NTSz znajdują się m.in. wspomnienia chorążego Petra Hołynskiego $^{82}$, przyszłego księdza, wikariusza generalnego Kościoła greckokatolickiego w Niemczech, związane z jego pobytem w 1920 r. w składzie UHA w zajętej przez bolszewików Odessie ${ }^{83}$, oraz relacje porucznika Stepana Maziara - w przyszłości księdza greckokatolickiego ${ }^{84}$ - dotyczące dziejów UHA w latach 1919-1920 ${ }^{85}$.

Wydawnictwo gromadziło rękopisy różnych autorów, bez względu na ich wykształcenie i status socjalny. Redakcja „Červonej Kaliny” m.in. ściśle współpracowała z byłym setnikiem 10. Pułku artylerii UHA Illą Rogatynskim, „zwykłym mieszkańcem wsi, nie pisarzem, i nie uczonym”, jak określał on siebie w liście do redakcji ${ }^{86}$. W omawianym zasobie, oprócz listów ${ }^{87}$, znajdują się rękopisy I. Rogatynskiego - wspomnienia, m.in. o poruczniku W. Gałanie, oraz utwory literackie ${ }^{88}$. Imiona niektórych autorów wspomnień i dzienników przechowywanych w archiwum pozostają dla nas nieznane, jak na przykład starszyny (podoficera) VI. Brygady Rawskiej UHA, którego dziennik wojenny za sierpień - listopad 1919 r. ${ }^{89}$ przekazał do redakcji w 1935 r. niejaki Wołowyj.

78 Więcej о nim zob. Я. Тинченко, Офіцерський корпус Армї Української Народної Республіки (1917-1921). Кн. 2, Київ 2011, s. 298.

79 Więcej o nim zob. П. Сов'як, Тільки про одну книжку, [w:] Дрогобицький книгознай. Вип. 1, Дрогобич 2009, s. 11-13.

80 Więcej o nim zob. М. Романюк, Зубенко Іван Сергійович, [w:] Енциклопедія Сучасної України, [online] http://esu.com.ua/search_articles.php?id=13935 [dostep 04.05.2021].

81 Wspomnienia O. Babija pt. „Наступ над Серетом” oraz „Стрілецькі чоботи. (3 моїх споминів)" zob. sygn. 21/53/2/1, k. 75-78; 21/53/3/1, k. 18-27; wspomnienia O. Dumina - sygn. 21/53/2/1, k. 1-38, 40-63; wspomnienia D. Gonty pt. „Поєдинок першої гармати Чорношличників 3 ворожим панцерником” oraz „Останні дні боїв 1920 р.” zob. sygn. 21/53/2/1, k. 116-118; 21/53/2/4, k. 1-9; przemówienia I. Kaliczaka pt. „Шевченко Українській Арміі” oraz „Над стрілецькою могилою” zob. sygn. 22/53/21, 18 k.; 21/53/25/1-4, k. 1-7; zbiór wspomnień i relacji I. Zubenki pt. „Наші лицарі і мученики” przechowywany w teczce o sygn. 22/53/22, k. 133-224, został wydany w Kaliszu w 1922 r., zob. I. Зубенко, Намі лицарі і мученики. Ч. 1, Каліш 1922.

82 Więcej o nim zob. I. Лебедович, Полеві духовники УГА: у 45-річчя участі у Визвольних Змаганнях, Вінніпег 1963, s. 230.

83 Sygn. 21/53/5/2, k. 21-32.

84 Więcej o nim zob. Б. Прах, Духовенство Перемиської єпархї та Апостольської адміністрації Лемківщини. Т. 1, Львів 2015, s. 164.

85 Sygn. 21/53/5/4, zesz. I, 57 k.

86 Sygn. 21/53/5/2, k. 19.

87 Sygn. 21/53/2/8, k. 99; 21/53/5/2, k. 16-19, 86.

88 Sygn. 21/53/2/8, k. 95-99; 21/53/5/2, k. 75-85, 87-95.

89 Sygn. 21/53/2/8, k. 175-252. 
W jego zapisce dołączonej do dziennika zaznaczono jedynie, że notes trafił do niego od nieznanego starszyny wspomnianej wyżej Brygady ${ }^{90}$; sam zeszyt oznaczono pieczątką tej jednostki wojskowej.

Kobiecym głosem wśród wspomnień wojennych żołnierzy są obszerne relacje Iryny z Budzynowskich Ołes'kowej, nauczycielki z powiatu żółkiewskiego, w których opisuje swoje życie w obozie dla uchodźców z Galicji w Gmindzie (Austria), gdzie razem ze swoimi dziećmi przebywała w latach 1916-1918 dopóki jej mąż walczył na froncie ${ }^{91}$. Fragment wspomnień razem $z$ informacją o autorce został opublikowany w „LČKK” w 1939 r. ${ }^{92}$

\subsubsection{Dzieła literackie}

Oprócz wspomnień i relacji związanych z ukraińskim ruchem niepodległościowym lat 1917-1921, wydawnictwo „Červona Kalina” publikowało również utwory literackie. Prace te ukazywały się drukiem na stronach czasopism „LČKK” i „IKAČK” oraz jako osobne wydania.

W omawianej części archiwum NTSz znajdują się m.in. autografy dzieł Mychajła Seredy, byłego podpułkownika Armii URL ${ }^{93}$, który ściśle współpracował z „Červoną Kaliną”. Archiwum zawiera materiały do zbioru jego opowiadańn ${ }^{94}$ rękopisy pięciu utworów i projekt okładki-który autor prawdopodobnie zamierzał opublikować w wydawnictwie ${ }^{95}$, oraz fragment pracy publicystycznej pt. „Серед Запорожців”, w której został opisany okres Hetmanatu (Państwa Ukraińskiego) oraz Dyrektoriatu (II URL) ${ }^{96}$. Z licznych prac pisarza i dziennikarza Fedora Dudki ${ }^{97}$, opublikowanych przez „Červoną Kalinę”, zachował się autografjego opowiadania „Дісонанс"

$\mathrm{W}$ archiwum znalazły się m.in. autografy utworów poetyckich Iwana Baluka, żołnierza Legionu USS, który w 1915 r. w wieku 21 lat zginął w walce $\mathrm{z}$ armią rosyjską ${ }^{101}$. Wybór wierszy napisanych przez młodego autora w latach

90 Tamże, k. 173.

91 Maszynopis, fragment bez początku i podpisu autorki. Sygn. 21/53/3/1, k. 84-161.

92 І. Олеськова, Периий день у Гмінді, ,Літопис Червоної Калини” 1939, ч. 6, s. 4-7.

93 Więcej o nim zob. Я. Тинченко, Офіцерський корпус Армї Української Народної Республіки (1917-1921). Кн. 1, s. 394-395.

94 Sygn. 21/53/1/1, [2], $160 \mathrm{k}$.

95 Zbiór nie ukazał się drukiem.

96 Sygn. 21/53/3/1, k. 182-215.

97 Zob o nim: Г. Герасимова, Дудко Федір, [w:] Енциклопедія історії України : у 10 m. Т. 2 , редкол. В.А. Смолій (голова) та ін., Київ 2004, s. 490.

98 Sygn. 21/53/5/5, k. 48-50.

99 Sygn. 21/53/6/2, k. 33.

100 Ф. Дудко, Квіти і кров. Фільми украӥнської боротьби 1919-1920 рр., Львів 1928.

101 Więcej о nim zob. К. Науменко, Балюк Іван, [w:] Енциклопедія історї Украӥни : y 10 m. Т. 1, редкол. В.А. Смолій (голова) та ін., Київ 2003, s. 177. 
1912-1914 ${ }^{102}$ trafił do Myrona Zakłynskiego, pisarza, działacza społecznego, setnika Legionu USS, który w 1927 r. wysłał rękopisy w celu ich publikacji do redakcji czasopisma „Літературно-Науковий Вістник”, skąd później trafiły do redakcji „Červonej Kaliny”. W swoim liście dołączonym do rękopisów Baluka, Zakłynskyj nazywa autora nie tylko „wybitną postacią” i ,utalentowanym poetą", ale nawet ocenia go jako „najzdolniejszego poetę w Galicji w wojennym i powojennym okresie" 103 . Mimo to w wydawnictwie „Červona Kalina” nie ukazał się drukiem żaden utwór I. Baluka. Kilka wierszy w 1917 r. weszło do publikacji zbiorowej pt. „Стрілецький Календар-Альманах Пресової Кватири У.С.В... ${ }^{104}$, poszczególne dzieła zostały opublikowane $\mathrm{w}$ antologiach poetyckich ${ }^{105}$ dopiero pod koniec XX i na początku XXI w.

W analizowanym zbiorze znajdują się autografy dzieł znanych pisarzy, którzy odgrywali ważną rolę w ukraińskim procesie literackim i wydawniczym pierwszej połowy XX w. Warto m.in. wymienić autografy wierszy Bohdana-Ihora Antonycza ${ }^{106}$ : „До розстріляних поетів” і „Слово про полк піхоти”"107; rękopis poematu „Пісня про Гутне - квіт Бавовни!”108 Petra Franki, pilota wojskowego UHA, pisarza, naukowca, pedagoga, sportowca, syna jednego z najwybitniejszych ukraińskich pisarzy I. Franki ${ }^{109}$; maszynopis Bohdana Łepkiego ${ }^{110}$, pisarza, thumacza, działacza społecznego, profesora Uniwersytetu Jagiellońskiego, dotyczący ukraińskiej historii, kultury i literatury, zatytułowany „Історія України”"111; autograf opowieści Jurija Horlisa-Horskiego ${ }^{112}$ pt. „Це було давно" ${ }^{113}$; rękopisy dzieł Anatola i Jarosława Kurdydyków ${ }^{114}$ $\mathrm{i}$ inne.

102 Sygn. 21/53/2/5, zesz. II-III.

103 Tamże, zesz. II, k. 38-39.

104 Стрілеиький Календар-Альманах Пресової Кватири У.С.В. в полі на звичайний рік 1917, Львів 1917.

105 Стрілецька Голгофа: спроба антологї̈, упорядник, автор вступної статті і приміток Т.Ю. Салига, Львів 1992; Ю. Винничук, Розіп'ята муза, Львів 2011.

106 Zob. o nim w języku polskim: A. Ksenicz, B.I. Antonycz - urodzony w Galicji, „Slavia Orientalis" 1999 , t. 48, nr 1, s. 19-29.

107 Sygn. 21/53/3/2, k. 283-284.

108 Sygn. 21/53/5/4, zesz. III, $42 \mathrm{k}$.

109 Więcej o nim zob. К. Науменко, Франко Петро Іванович, [w:] Енциклопедія історії України : у 10 m. Т. 10, редкол. В.А. Смолій (голова) та ін., Київ 2013, s. 325.

110 Więcej o nim w języku polskim zob. R. Łużny, Bohdan Łepki (1872-1941), [online] https://ruj.uj.edu.pl/xmlui/bitstream/handle/item/265186/luzny_bohdan_lepki_1872-1941_2000.pdf?sequence $=1 \&$ isAllowed $=y$ [dostęp 03.05.2021].

111 Sygn. 21/53/6/2, k. 94-141. Sam tekst tytułu nie zawiera. Nazwa dzieła oraz imię autora są wymienione na okładce teczki, w której umieszczono maszynopis.

112 Więcej o nim zob. Г. Герасимова, Горліс-Горський Юрій Юрійович, [w:] Енииклопедія історї України : у 10 m. Т. 2, редкол. В.А. Смолій (голова) та ін., Київ 2004, s. 167.

113 Sygn. 21/53/2/6, k. 85-129.

114 Sygn. 21/53/6/2, k. 64-71. 
$\mathrm{Na}$ bardzo cenny materiał w analizowanym zbiorze składają się maszynopisy z fragmentami dramatu groteskowego napisanego dla ukraińskiego teatru lalek pt. „Вертеп наших днів” (dalej: „Vertep naših dnìv”) ${ }^{115}$ założonego w 1926 r. przez Łewa Łepkiego i Romana Kupczyńskiego, pisarzy, dziennikarzy, działaczy społecznych, redaktorów wydawnictwa "Červona Kalina”"116. Głównym celem „Vertepu naših dnìv”, który wywodził się od tradycyjnego ukraińskiego obnośnego teatru kukiełkowego (podobnego do polskiej szopki), było przedstawienie ówczesnego życia społecznego Galicji z naczelnym nastawieniem na politykę i kulturę. Pokazywane w całej Galicji spektakle teatru odnosiły wielki sukces, dlatego w latach 1929-1930 „Vertep” z nowym repertuarem odbył trasę po Ameryce ${ }^{117}$. Ze względu na różną, nie zawsze przychylną reakcję lokalnej publiczności, po powrocie do domu w działalności teatru nastąpiła długa przerwa. Dopiero w 1948 r. przebywając w obozie dla uchodźców w miasteczku Blonhofen w Bawarii, Ł. Łepkyj z udziałem R. Kupczyńskiego stworzył kolejną wersję „Vertepu”. Po emigracji do Stanów w 1949 r. Ł. Łepkyj opracował następną edycję dramatu. W lwowskich czasopismach humorystycznych ukazało się drukiem kilka fragmentów z „Vertepu naših dnìv” 118 , losy większości tekstów pozostałych w formie rękopisów i maszynopisów są dzisiaj nieznane. Pod tym względem maszynopisy ze zbioru Ossolineum, które posiadają liczne prawki i adnotację autorskie, niewątpliwie stanowią cenny materiał badawczy dla literaturoznawców i historyków literatury ukraińskiej.

Wśród autografów z materiałów redakcyjnych wydawnictwa „Červona Kalina" przechowywanych dzisiaj w Ossolineum znajduje się rękopis powieści „На еміграціï” 119 Walerii O'Konnor-Wilinskiej ${ }^{120}$, pisarki, publicystki, działaczki społecznej i politycznej, spółzałożycielki Ukraińskiej Centralnej Rady ${ }^{121}$. Powieść stworzona w 1927 r. na emigracji w Podiebradach (Czechy) opowiada o życiu ówczesnych ukraińskich emigrantów, m.in. o pierwszych

115 Dalej w tekście podaję formę transliterowaną zgodnie z normą ISO 9:2000. Szerzej o działalności teatru zob. Н. Стрілець, Вертеп наших днів - гумористичний барометр галищького суспільства, [online] http://www.lepkiy.te.ua/index.php/uk/statti-ta-uchast-u-konferentsiiakh [dostęp 25.04.2021].

116 Więcej o Ł. Łepkim zob. О. Луцький, Лепкий Лев Сильвестрович, [w:] Енциклопедія історії України : у 10 m. Т. 6, редкол. В.А. Смолій (голова) та ін., Київ 2009, s. 125; о R. Кupczynskim zob. Г. Герасимова, Д. Грузін, Купчинський Роман Григорович, [w:] Енциклопедія історії України : у 10 m. Т. 5, редкол. В.А.Смолій (голова) та ін., Київ 2009, s. 508.

117 O pobycie teatru w Ameryce zob. Bертеп наших днів, „Svoboda” 21 VI 1930, № 143, s. 3.

118 Zob. m.in.: Beтеп наших днів (виїмок з III-ої діï), „Зиз” 1 VI 1928, № 11, s. 3-4.

119 Sygn. 22/53/23, $308 \mathrm{k}$.

120 Więcej o autorce zob. Т. Осташко, О’Коннор-Вілінська Валерія Олександрівна, [w:] Енциклопедія історії Украӥни : у 10 m. Т. 7, редкол. В.А. Смолій (голова) та ін., Київ 2010, s. 555.

121 Więcej o Ukraińskiej Centralnej Radzie jako parlamentarnym organie państwowym Ukrainy zob. T.A. Olszański, Historia Ukrainy XX wieku, Warszawa 1991, s. 38. 
przedstawicielstwach dyplomatycznych i dyplomatach URL. W notatce adresowanej do czytelnika autorka zaznacza, że większość wydarzeń opisanych w powieści, jest prawdziwa, natomiast postacie są fikcyjne, a wszystkie podobieństwa do prawdziwych osób są przypadkowe ${ }^{122}$. Powieść W. O'Konnor-Wilinskiej na podstawie rękopisu ze zbiorów $\mathrm{ZNiO}$ po raz pierwszy ukazała się drukiem dopiero w 2005 r. $^{123}$ dzięki staraniom ówczesnego konsula Ukrainy w Krakowie O. Medownikowa.

\subsubsection{Artykuły}

Oprócz wspomnień i dzieł literackich w czasopismach „Červonej Kaliny” publikowano także artykuły publicystyczne i naukowe najczęściej związane z ukraińską historią. W archiwum NTSz z ossolińskiej kolekcji zachowały się autografy tekstów poświęconych głownie kozakom i Siczy Zaporoskiej, m.in. artykuł historyka Mychajła Antonowycza pt. „Кенінгзберзькі архівні матеріали до історії Козаччини в першій половині XVII століття" 124 opublikowany w „LČK” " w 1936 r. ${ }^{125}$, teksty nieznanych z imienia S.F. Łantucha pt. „Устрій запорожської Ради” 126 i S. Żuka pt. „В 300 літні роковини I. Мазепи”'27, artykuł dr Sergija Fedorowa pt. „Військо Запорожське Держава Богдана Хмельницького"128 i inne.

Bardzo ciekawym dokumentem do historii ukraińskiego ruchu studenckiego w Polsce jest artykuł Bogdana-Adama Kabariwskiego ${ }^{129}$ o ukraińskich korporacjach studenckich, m.in. o stowarzyszeniu Чорноморе założonym przez niego w Krakowie w 1928 r. ${ }^{130}$ Do rękopisu dołączono zdjęcie z 1930 r., na którym przedstawiono członków organizacji131. Mimo nadziei autora, że jego „marny artykuł”132 ukaże się w „LČK“", tekst do dzisiaj pozostaje jedynie w formie rękopisu.

122 Sygn. 22/53/23, k. 10 v.

123 В. О'Коннор-Вілінська, На еміграиії: роман-хроніка, Львів 2005.

124 Sygn. 21/53/3/1, k. 1-10.

125 М. Антонович, Новий документ до історії повстання Остряниці. Кенінтсберзькі архівні матеріали до історії Козаччини в першій половині XVII століття, „Літопис Червоної Калини" 1936, ч. 7-8, s. 35-38.

126 Sygn. 21/53/3/1, k. 43-60.

127 Sygn. 21/53/2/5, zesz. IV, k. 1-8.

128 Sygn. 21/53/3/2, k. 226-236.

129 В. Качан, Кабарівський Богдан-Адам Іванович, [w:] Енииклопедія Сучасної Украӥни, [online] http://esu.com.ua/search_articles.php?id=11954 [dostęp 13.04.2021].

130 Sygn. 21/53/2/1, k. 66-72.

131 Tamże, k. 73.

132 Tamże, k. 65. 


\subsubsection{Inne materiały redakcyjne}

Bardzo cennym źródłem do historii ukraińskiego ruchu wydawniczego pierwszej połowy XX w. są materiały redakcyjne „Červonej Kaliny” związane z przygotowaniem do druku wydań, które z różnych przyczyn nigdy nie zostały opublikowane w swoim pierwotnym wariancie. Chodzi o publikacje zbiorowe „Золоті Ворота. Альманах Січових Стрільців”133 oraz „Белз і Белжчина”.

Praca nad wydaniem pierwszej z wymienionych monografii, poświęconej dziejom Strzelców Siczowych - formacji Armii URL (1917-1919) - została rozpoczęta w Wiedniu w latach 20. XX w. Mimo prawie zakończonego procesu wydawniczego, ze względu na problemy finansowe i organizacyjne, do wydania almanachu, który w 1924 r. miał ukazać się w berlińskiej oficynie „Ukrainske Slowo"134, nie doszło. Część tekstów została utracona lub wydana w innych publikacjach, pozostałą część nabyło wydawnictwo „Nasze Słowo" z Przemyśla, które planowało opublikować uzupełniony materiał na początku lat 30. Ze względu na wydarzenia związane z pacyfikacją Małopolski Wschodniej w 1930 r., wydanie i tym razem nie zostało zrealizowane. Po raz pierwszy książka pt. Золоті Ворота. Історія Січових Стрільиів ukazała się drukiem w wydawnictwie „Červona Kalina” w 1937 r. ${ }^{135}$ Z pierwotnej wersji wydania, która składała się z kilku części i zawierała kilkadziesiąt artykułów i utworów literackich, do publikacji z 1937 r. weszły tylko dwa teksty - Wasyla Kuczabskiego i Marka Bezruczki, a także niektóre fotografie, diagramy i schematy. W omawianej części archiwum NTSz zachowały się materiały redakcyjne periodyku „Ukrainske Slowo” z lat 20. XX w., m.in. maszynopisy sześciu artykułów $\mathrm{z}$ historycznej części almanachu ${ }^{136}$, fragment egzemplarza korektorskiego z redaktorskimi prawkami i adnotacjami ${ }^{137}$, zdjęcia, materiały ilustracyjne (wydruki i odbitki ręczne) ${ }^{138}$, plan prac nad wydaniem i inne ${ }^{139}$. O przemyskim etapie prac nad almanachem i o jego zawartości informuje

133 Referat pt. «Золоті Ворота. Альманах Січових Стрільців» : до історіїнереалізованого видавничого проєкту (на архівних матеріалах НТШ зі збірки відділу рукописів Наиіонального інституту ім. Оссолінських у Вроилаві) został wygłoszony przez autorkę niniejszego artykułu w trakcie Międzynarodowej Konferencji Naukowej „Lwowska Narodowa Naukowa Biblioteka Ukrainy im. W. Stefanyka: historia, źródła, ludzie" (Lwów, 20-21 lutego 2021 r.). Tekst referatu powinien ukazać się drukiem w materiałach pokonferencyjnych.

134 Tytuł czcionką łacińską odpisano z pieczęci, którą oznaczono egzemplarz.

135 Золоті Ворота. Історія Січових Стрільиів, Львів 1937.

136 Są to artykuły Mykoły Kapustianskiego, Wałentyna Sadowskiego, Wołodymyra Salskiego, Hyppolita Olgerda Boczkowskiego, Mychajła Wozniaka oraz Iwana Krypiakewycza, zob. sygn. 21/53/4/1, k. $1-127$.

137 Sygn. 21/53/4/3, k. $1-66$.

138 Sygn. 21/53/4/4, k. 31-44.

139 Tamże, k. 21-25. 
druk ulotny dotyczący prenumeraty wydania przechowywany w omawianej części archiwum ${ }^{140}$.

Działania związane z wydaniem monografii o historii Bełza i ziem bełskich zostały rozpoczęte w 1935 r. dzięki staraniom Komitetu Społecznego Bełszczyzny pod kierownictwem ks. Iłariona Geły ${ }^{141}$. Prace nad przygotowaniem publikacji, która miała ukazać się w wydawnictwie "Červona Kalina", trwały kilka lat, ostatecznie do składu wydania weszły trzy rozprawy opracowane przez znanych historyków - Jarosława Pasternaka, Iwana Karpyncia i Teofila Kostrubę. Przygotowana do druku monografia pod koniec lat 30. została oddana do bazyliańskiej drukarni w Żółkwi. Niestety, wszystkie wydrukowane egzemplarze książki zostały zniszczone przez armię radziecką, która w 1939 r. okupowała Galicję. Większość materiałów redakcyjnych została również zniszczona lub rozproszona. Część materiałów przetrwała do dziś i w składzie archiwum NTSz jest przechowywana w zbiorach Ossolineum. Tekst J. Pasternaka pt. Доісторичні та княжі часи Белзчини ${ }^{142} \mathrm{w}$ formie rękopisu zachował się w całości; w artykule T. Kostruby pt. Белз і Белзька земля від найдавніших часів до 1772 року $1^{143}$, który zachował się w formie drukowanej, brakuje początku; z drukowanej rozprawy I. Karpyncia pt. Белз і Белжчина під Австрією ${ }^{144}$ przetrwały jedynie początkowe karty. Skomplikowany proces przygotowania monografii do druku przedstawiono w korespondencji Komitetu Społecznego Bełszczyzny z wydawnictwem i autorami wydania ${ }^{145}$.

Ważną część materiałów redakcyjnych „Červonej Kaliny” niewątpliwie stanowi korespondencja. Listy które znajdują się w zbiorach Ossolineum, przede wszystkim przedstawiają szczegóły współpracy wydawnictwa z autorami, ale także dostarczają cennych informacji na temat warunków ich życia ${ }^{146}$. Oprócz listów do redakcji „Červonej Kaliny” oraz redakcji jej czasopism, w omawianym zasobie znajdują się listy do redakcji czasopisma humorystycznego „Зиз” i jej redaktora Ł. Łepkiego ${ }^{147}$ oraz nieliczna korespondencja Dmytra Doncowa jako redaktora czasopisma „Літературно-Науковий Вістник”148.

140 Tamże, k. 47.

141 Т. Коструба, Белз і Белзька земля. Від найдавніших часів до 1772 року, Н'ю-ЙоркТоронто 1989, s. 8 .

142 Sygn. 21/53/5/3, k. 251-298. Rozprawę J. Pasternaka opublikowano w: Надбужанщина : Сокальщина, Белзчина, Радехівщина, Камінеччина, Холмщина і Підляшшя : історично-мемуарний збірник. Т. 1, Н'ю-Йорк-Париж-Сидней-Торонто 1986, s. 149-164.

143 Sygn. 21/53/5/3, k. 300-335. Tekst T. Kostruby w osobnym wydaniem ukazał się w 1989 r., zob. Т. Коструба, Белз і Белзька земля. Від найдавніших часів до 1772 року...

144 Sygn. 21/53/5/3, k. 336-339.

145 Sygn. 21/53/5/5.

146 Korespondencję umieszczono w różnych teczkach zasobu, zob. sygn. 21/53/1/1-21/53/6/2.

147 Sygn. 21/53/6/2.

148 Sygn. 21/53/6/1, k. 94; 21/53/6/2, k. 29. 
Wśród innych dokumentów pochodzących z materiałów redakcyjnych wydawnictwa „Červona Kalina”, które są przechowywane w Ossolineum, warto wymienić szkicownik Leonida Baczynskiego ${ }^{149}$, który zawiera portrety żołnierzy Armii URL przebywających w obozie dla internowanych w Lańcucie w 1920 r. ${ }^{150}$; egzemplarz albumu Українські Січові Стрільиі: ілюстраційний додаток ${ }^{151}$; egzemplarz wydania Жалібна книга: Поіменний спис поляглих членів У.Г.А. у визвольній війні ${ }^{152}$; zdjęcia przedstawiające dowódców Armii URL oraz oficerów Wołyńskiej i Zaporoskiej Dywizji na wychodźstwie ${ }^{153}$; egzemplarze ukraińskich gazet i czasopism z pierwszej połowy XX w. ${ }^{154}$ i inne.

Cennym źródłem do historii wydawnictwa „Červona Kalina” są przechowywane w analizowanym zbiorze „Indeksy autorów, artykułów, ilustracji oraz nazw geograficznych zamieszczonych w İKAČK”" za lata $1925-1938^{155}$ oraz „Wykaz rękopisów wysłanych do redakcji wydawnictwa do 1935 r." ${ }^{156}$

W teczkach z materiałami redakcyjnymi „Červonej Kaliny” są przechowywane także dokumenty pochodzące $\mathrm{z}$ innych zbiorów. Wśród nich na uwagę m.in. zasługują: „Spis jeńców i internowanych Ukraińców z Naddnieprza w Dąbiu koło Krakowa, 1920 r." ${ }^{157}$; rozporządzenia i komunikaty dowództwa Ukraińskiej Brygady w obozie dla internowanych żołnierzy UHA (Jablonné v Podještědí, Czechy), 1921 r. ${ }^{158}$; papiery „Centrosojuzu” (Związku Spółdzielczych Związków) we Lwowie, m.in. spis członków, obwieszczenia ${ }^{159}$ $\mathrm{i}$ inne.

149 L. Baczynski, ukraiński pisarz, pedagog i publicysta; więcej o nim zob. В. Стасенко, Бачинський Леонід Васильович, [w:] Енциклопедія Сучасної України : у 30 m. Т. 2, Київ 2003, s. $335-336$.

150 Sygn. 21/53/2/3, zesz. IV. W publikacji Tarnów - siedziba władz URL..., rysunki te przypisano nieznanemu autorowi, zob. Tarnów - siedziba władz Ukraińskiej Republiki Ludowej..., s. 14. Jednak pieczątka L. Baczynskiego na szkicowniku i wpis w „Wykazie rękopisów wysłanych do wydawnictwa” świadczą, że autorem jest L. Baczynski [zob. sygn. 21/53/6/2, k. 145-151].

151 Украӥнські Січові Стрільиі: ілюстрачійний додаток, Львів 1936. Sygn. 21/53/2/1, k. $127-137$.

152 Жалібна книга: Поіменний спис поляглих членів У.Г.А. у визвольній війні. Ч. 1, Львів [1922]; Ч. 2, Жовква [1922]. Sygn. 21/53/4/4, k. 48-89.

153 Sygn. 21/53/3/2, k. 1-4.

154 Sygn. 21/53/6/2, 20/53.

155 Sygn. 21/53/4/2, $167 \mathrm{k}$.

156 Sygn. 21/53/6/2 k. 145-151.

157 Sygn. 21/53/1/2, k. 127-136.

158 Sygn. 21/53/2/4, k. 108-112.

159 Sygn. 21/53/6/2, k. 75-84. 


\subsection{Archiwum Sztabu Partyzancko-Powstańczego przy Głównej Komendzie Armii URL}

Po emigracji Centrum Państwowego i wycofaniu się Armii URL na terytorium Polski, w styczniu 1921 r. Główna Komenda podjęła decyzję o zorganizowaniu akcji powstańczej na terenach USRR. W tym celu zgodnie z rozkazem Symona Petlury od 18 II 1921 r. został utworzony Sztab Partyzancko-Powstańczy ${ }^{160}$ podległy bezpośrednio Naczelnemu Atamanowi. Organizację sztabu powierzono gen. Jurkowi (Juriju) Tiutiunnykowi, dowódcy 4 Dywizji Kijowskiej. Do organizowania działalności SPP dołączył się Sztab Generalny Wojska Polskiego, który oprócz finansowania i zaopatrzenia SPP w niezbędne dokumenty, zobowiązał się zwolnić z obozów ukraińskich żołnierzy potrzebnych do organizacji powstania ${ }^{161}$.

Swoją działalność SPP rozpoczął w Tarnowie, w czerwcu 1921 r. został przeniesiony do Lwowa. Struktura SPP niejednokrotnie się zmieniała, ostatecznie zostały utworzone dwa wydziały - Zarząd Cywilny (pod kierownictwem ppłka Josypa Dobrotworskiego) i Zarząd Wojskowy (na czele z płkiem Sztabu Generalnego Armii URL Jurijem Otmarsztejnem) - podzielone na mniejsze wydziały i sekcje ${ }^{162}$. W skład Zarządu Cywilnego wchodzili urzędnicy delegowani przez ministerstwa URL, a mianowicie Ministerstwa Kolei, Poczty i Telegrafów, Spraw Wewnętrznych oraz Prasy i Propagandy. Do struktury Zarządu Cywilnego należała sekcja wywiadowcza pod kierownictwem ppłka Ołeksandra Kuzminskiego, która utrzymywała sieć punktów kontrolno-etapowych przy granicy z USRR. Mimo rozbicia przez CzeKa konspiracji SPP i fatalnego stanu wyposażenia oddziałów, w listopadzie zaczęła się wyprawa powstańców na terytorium USRR ${ }^{163}$ przeprowadzona przez trzy grupy: główną - wołyńską (pod dowództwem gen. J. Tiutiunnyka), besarabską (pod dowództwem gen. Andrija Hułego-Hułenki) i podolską (pod dowództwem ppłka Mychajła Palija-Sydorjanskiego). Rajd zakończył się całkowitym rozbiciem

160 Więcej na ten temat w języku polskim zob. J.J. Bruski, Petlurowcy. Centrum Państwowe Ukraińskiej Republiki..., s. 295; zob. też В. Кучер, Партизансько-Повстанський штаб як центр протибільшовицького руху опору на Украӥні 1921 року, „Воєнна Історія” 2011, № 1 (55), s. 37-49; В. Василенко, Підготовка антибільшовищького повстання в Украӥні у 1921 р. (за документами ГДА Служби безпеки України), „З архівів ВУЧК - ГПУ - НКВД - КГБ ” 2008, № 1/2 (30/31), s. 139-197 i inne.

161 J.J. Bruski, Petlurowcy. Centrum Państwowe Ukraińskiej Republiki Ludowej..., s. 296.

162 В. Василенко, Підготовка антибільшовицького повстання..., s. 158.

163 W literaturze rajd żołnierzy Armii Czynnej URL przeprowadzony na terytorium USRR w październiku-listopadzie 1921 r. nazywano II pochodem zimowym, zob. m.in. J.J. Bruski, Petlurowcy. Centrum Państwowe Ukraińskiej Republiki Ludowej..., s. 294; Г.Савченко, Другий зимовий похід армії УНР 1921, [w:] Енциклопедія історії Украӥни : у 10 m. Т. 2, редкол. В.А.Смолій (голова) та ін., Київ 2004, s. 473. 
sił ukraińskich, co, zdaniem badaczy, spowodowało „trudny do przecenienia wpływ na środowisko ukraińskiej emigracji”"164.

Na Ukrainie materiały z archiwum SPP są przechowywane w różnych instytucjach ${ }^{165}$. W Polsce fragmenty analizowanego archiwum są zlokalizowane w BN w Warszawie ${ }^{166}$ oraz w ZNiO. Na ossoliński zbiór składa się 14 teczek ${ }^{167}$, w których zgromadzone są głównie kopie i bruliony dokumentów, oznaczonych klauzulą „tajne” i ,ściśle tajne”, dotyczących działalności SPP związanej z przygotowaniem powstania na Ukrainie w $1921 \mathrm{r}$.

$\mathrm{W}$ analizowanym zasobie znajdują się dokumenty dotyczące tworzenia SPP oraz jego struktury organizacyjnej. Są to m.in. bruliony rozporządzenia J. Tiutiunnyka z 18 II 1921 r. w sprawie założenia SPP, które zawiera informację o pierwotnej strukturze Sztabu ${ }^{168}$; schemat organizacyjny SPP ${ }^{169}$; program posiedzenia dotyczący tworzenia „Ewidencji II”, Działu Informacyjnego (Wywiadowczego) SPP 170 ; projekt organizacji Służby Informacyjnej i Prasowej przy SPP ${ }^{171}$; rozkaz z 17 X 1921 r. o założeniu przy Ekspozyturze Sztabu Generalnego Wojska Polskiego we Lwowie Ukraińskiego Biura Prasowo-Informacyjnego pod kierunkiem M. Suchodolskiego-Peresady ${ }^{172}$ i inne.

Ważną część zasobu stanowią papiery J. Tiutiunnyka związane z jego działalnością jako dowódcy SPP. Jest to przede wszystkim korespondencja służbowa - listy, zapiski, podania, raporty, sprawozdania od żołnierzy i dowódców oddziałów powstańczych, m.in. od Andrija Hułego-Hułenki, Serhija Jaworskiego („Karego”), Iwana Kuzmenki-Tytarenki, Tychona Besarabenki, Dmytra Hałajdy-Polakiwa, Iwana Hołuba i innych; korespondencja z kierownikami i pracownikami SPP, m.in. z Josypem Dobrotworskim, Jurijem Otmarsztejnem, O. Kuzminskim, Pawłem Stupnyckim i z innymi; z ministrami URL, m.in. z Mykołą Junakiwym, Mychajłem Omelanowyczem-Pawłenkiem, Serhijem Tymoszenkiem, Wołodymyrem Salskim, Markiem Bezruczkiem oraz inne; z dowódcami Armii URL, m.in. z Antonem Krawsem, Wasylem Nelgowskim, Wiktorem

164 J.J. Bruski, Petlurowcy. Centrum Państwowe Ukraińskiej Republiki Ludowej..., s. 317.

165 Materiały z archiwum SPP są m.in. przechowywane w Wydzielonym Państwowym Archiwum Służby Bezpieczeństwa Ukrainy (Галузевий державний архів Служби безпеки України), Centralnym Państwowym Archiwum Wyższych Organów Władzy i Administracji Ukrainy (Центральний державний архів вищих органів влади та управління України) oraz Centralnym Państwowym Archiwum Organizacji Społecznych Ukrainy (Центральний державний архів громадських об'єднань України), zob. В.Василенко, Підготовка антибільшовищького повстання..., s. 139 (przyp. 1).

166 Г. Сварник, Архівні та рукописні збірки..., s. 218-230.

167 Sygn. 22/53/2, 22/53/5/1-2, 22/53/6/1-2, 22/53/7/1-2, 22/53/10/1-4, 22/53/17/1-3.

168 Sygn. 22/53/5/1, s. 4, 258.

169 Sygn. 22/53/6/1, k. 67-69.

170 Sygn. 22/53/5/1, s. 115-116.

171 Sygn. 22/53/17/1, k. 101-102.

172 Sygn. 22/53/10/3, k. 122. 
Zelinskim i innymi; z Kancelarią Naczelnego Atamana i samym S. Petlurą ${ }^{173}$. W archiwum znajdują się autografy kilku listów S. Petlury do J. Tiutiunnyka - są to wytyczne i rozporządzenia dotyczące przygotowania powstania ${ }^{174}$. Jeden list z 29 III 1921 r. napisany na blankiecie Przewodniczącego Dyrektoriatu i Naczelnego Atamana Wojsk URL, jest zaproszeniem na posiedzenie Rady Wojskowej $^{175}$. Z listów adresowanych przez J. Tiutiunnyka do S. Petlury w omawianym zbiorze zachowały się raporty i sprawozdania ${ }^{176}$, m.in. raport pt. „Становище, в якому опинилась Україна та їі Уряд на 1921 р. і засоби, потрібні для відбудови УНР”, dotyczący ówczesnej sytuacji rządu URL i jego przyszłości ${ }^{177}$.

Osobną grupę stanowi korespondencja związana z działalnością prowadzoną przeciwko URL przez atamanów Ananiego Wołyńca, Tychona Besarabenkę i Hryhorija Szczerbaniuka, na którą składają się m.in. listy J. Tiutiunnyka do Wiaczesława Prokopowycza, Prezesa Rady Ministrów URL, Jewhena Moszynskiego, Naczelnego Prokuratora Wojskowego URL, i ppłka SPP O. Kuzminskiego, a także listy do J. Tiutiunnyka od W. Prokopowycza i Kancelarii Naczelnego Atamana Wojsk URL ${ }^{178}$.

W archiwum są także przechowywane odezwy J. Tiutiunnyka w sprawie organizacji powstania na Ukrainie skierowane do ludności ukraińskiej ${ }^{179}$ oraz do oficerów i żołnierzy Armii Czerwonej ${ }^{180}$. Z osobistych papierów generała w omawianym zasobie znajduje się jego życiorys ${ }^{181}$ i charakterystyka jako dowódcy wojskowego napisana przez ppłka Ołeksija Łusznenkę ${ }^{182}$.

Wśród dokumentów związanych z działalnością SPP dotyczącą organizacji powstania, w analizowanym zbiorze są przechowywane m.in. akta dotyczące spraw personalnych żołnierzy i wywiadowców - arkusze ewidencyjne, karty zaopatrzenia, zaświadczenia o przebiegu służby wojskowej, paszporty i dokumenty podróży, zdjęcia, rekomendacje, listy polecające dla żołnierzy zgłoszonych do służby przy SPP ${ }^{183}$; raporty oficerów i żołnierzy delegowanych przez SPP o przybyciu na miejsce pełnienia służby lub wyjeździe $\mathrm{z}$ niego ${ }^{184}$; spisy

173 Korespondencja J. Tiutiunnyka rozproszona w teczkach o sygn. 22/53/2, 22/53/5/1-2, 22/53/6/1-2, 22/53/7/1-2, 22/53/10/1-4, 22/53/17/1-3.

174 Sygn. 22/53/7/1, k. 90-92; 22/53/17/1, k. 21, 22.

175 Sygn. 22/53/5/2, k. 6 .

176 Sygn. 22/53/5/1, k. 3, 12, 20; 22/53/5/2, k. 132-133, 172, 175, 226-228; 22/53/6/2, k. 31, 276-278; 22/53/7/1, k. 89 v.; 22/53/10/3, k. 36-38, 67; 22/53/17/1, k. 90.

177 Sygn. 22/53/7/2, k. 292-295.

178 Sygn. 22/53/5/2, k. 135-143, 145-150, 217.

179 Sygn. 22/53/17/1, k. 123-124.

180 Tamże, k. 125-126.

181 Sygn. 22/53/10/1, k. 49-56.

182 Tamże, k. 39-47.

183 Sygn. 22/53/2, 289 k.; 22/53/17/3, k. 2-7, 16-18, 20-69, 75-76, 78-79, 87, 95-97, 100-104, $111-125,135$.

184 Sygn. 22/53/5/1, k. 166-213;22/53/5/2, k. 351-352, 354-361, 363-366, 370, 372-376; 22/53/17/1. 
i wykazy żołnierzy Armii URL zaangażowanych w organizację powstania oraz oddelegowanych na Ukrainę w celu wykonania zadań specjalnych SPP ${ }^{185}$; spisy punktów kontrolno-etapowych SPP oraz wykaz oddelegowanych tam żołnierzy ${ }^{186}$; wykazy rejonów i punktów powstańczych na Ukrainie ${ }^{187}$.

W części archiwum SPP przechowywanej w Ossolineum znajdują się także materiały dotyczące zarządzania, składu kadr i struktury SPP oraz planu organizacji powstania na Ukrainie, m.in. objaśnienie do kosztorysu wydatków przeznaczonych na organizację powstania na Ukrainie; objaśnienie w sprawie dowodzenia powstaniem; projekt organizacji sztabu dowódcy armii powstańczej; regulaminy dotyczące reprezentacji rządu URL przy powstańczych i partyzanckich organizacjach na tyłach wroga; schematy planu organizacji powstania na Ukrainie oraz organizacji sztabu wojsk powstańczych ${ }^{188} \mathrm{i}$ inne.

W omawianym zasobie znajdują się rozkazy, rozporządzenia i instrukcje związane z przygotowaniem powstania na Ukrainie, w tym rozporządzenia o wysłaniu na miejsce pełnienia służby i świadectwa żołnierzy SPP; instrukcje dla kierowników placówek wywiadowczych podpisane głównie przez J. Tiutiunnyka, J. Dobrotworskiego i D. Hałajdę-Polakiwa ${ }^{189}$; instrukcja dotycząca organizacji powstania na Ukrainie Prawobrzeżnej ${ }^{190}$; rozkaz S. Petlury dla ludności ukraińskiej w sprawie wojsk powstańczych URL ${ }^{191}$; rozkazy i instrukcje SPP dotyczące zarządzania wojskowego i cywilnego ${ }^{192}$; krótka instrukcja dla żołnierzy wyjeżdżających na Ukrainę z 1 IV 1921 r. podpisana przez gen. J. Tiutiunnyka ${ }^{193} \mathrm{i}$ inne.

Dużą część omawianego zbioru stanowią materiały związane z działalnością wywiadowczą SPP. Są to głównie instrukcje, rozporządzenia, wytyczne, m.in. instrukcja dla służby wywiadowczej z 14 III 1921 r. ${ }^{194}$, instrukcja dla kierowników punktów kontrolno-etapowych SPP ${ }^{195}$, a także instrukcje do użytku kierowników punktów wywiadowczych ${ }^{196}$ oraz dla osób wysłanych na Ukrainę ${ }^{197}$ podpisane przez ppłka O. Kuzminskiego, instrukcja dotycząca komunikacji

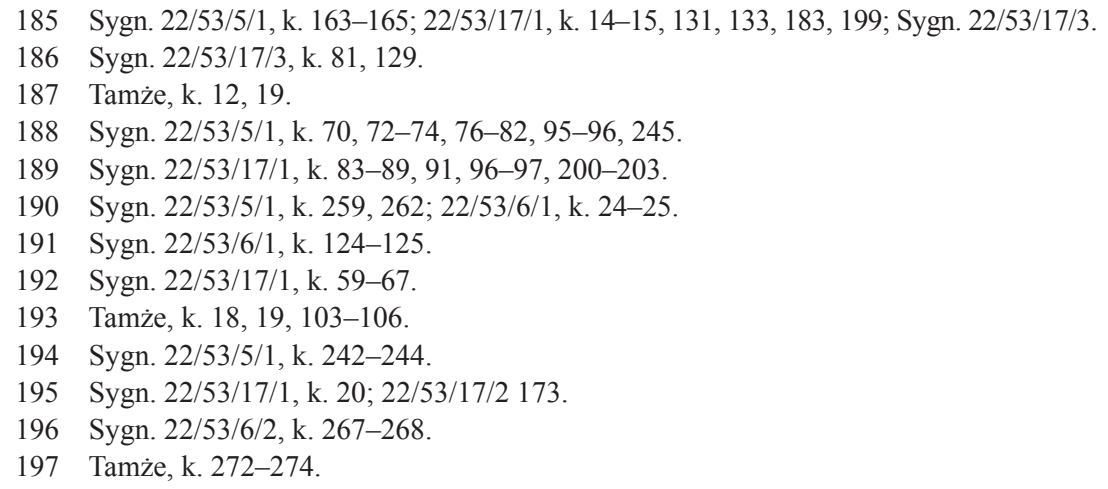


organizacji powstańczych"198, instrukcja dla Ewidencji II w zakresie prowadzenia działalności ewidencyjnej ${ }^{199}$, dwie instrukcje pt. „Координація акції регулярної армії і повстанців під час окремих фаз визвольної боротьби України”200 oraz „Меморіал що до найблизчих завдань на 1921 рік”201 przygotowane przez ppłka SPP Wilhelma Zejegorsza; formularze oraz wypełnione kwestionariusze i ankiety dla uchodźców z Ukrainy ${ }^{202}$; protokoły z zeznań i przesłuchań żołnierzy przybyłych z Ukrainy ${ }^{203}$; raporty, sprawozdania, powiadomienia i doniesienia wywiadowcze, szyfrogramy, klucze do ich odszyfrowania oraz odszyfrowane powiadomienia wywiadowcze ${ }^{204}$, w tym raporty Sekcji ds. Ewidencji SPP dotyczące sytuacji na Ukrainie z informacją o delegowaniu i działaniu tam oddziałów powstańczych ${ }^{205}$; mapy z zaznaczonym położeniem powstańczych oddziałów i organizacji; doniesienia o składzie i dyslokacji oddziałów partyzanckich SPP oraz oddziałów Armii Czerwonej na Ukrainie ${ }^{206}$; dokumenty służbowe i osobiste żołnierzy Armii Czerwonej, uzyskane przez wywiadowców SPP, m.in. karty ewidencyjne, legitymacje, zaświadczenia ${ }^{207} i$ inne.

W teczce o sygn. 22/53/10/2 umieszczono 13 kopert z doniesieniami wywiadowczymi SPP, które zawierają dane dotyczące składu, dyslokacji i przemieszczania się oddziałów Armii Czerwonej oraz Wojsk Wszechrosyjskiej Komisji Nadzwyczajnej, informację o bolszewickich uczelniach wojskowych, o ruchu kolejowym i transporcie wojsk, dane dotyczące funkcjonowania punktów telegraficznych, telefonicznych i pocztowych itp. Doniesienia zawierają również dane osobowe żołnierzy Armii Czerwoneje8 .

Oprócz materiałów Sekcji Wywiadowczej, w omawianym zbiorze są zawarte dokumenty innych działów i sekcji działających w strukturze SPP, m.in. Referatu Wojskowego, Działu Transportowego, Zarządu Cywilnego oraz Biura Prasowo-Informacyjnego.

Wśród papierów Działu Transportowego SPP i Ministerstwa Kolei URL, znajduje się korespondencja, a także wytyczne i instrukcje, m.in. odezwa i instrukcja SPP dla kolejarzy Ukrainy w sprawie organizacji powstania ${ }^{209}$; regulaminy, listy stanowisk, kalkulacja wynagrodzeń pracowników; plany i schematy

198 Tamże, k. 290-291.

199 Tamże, k. 299-300.

200 Tamże, k. 223-228.

201 Tamże, k. 229-247.

202 Sygn. 22/53/5/2, 22/53/6/2, k. 269-271; 22/53/7/2, k. 291.

203 Sygn. 22/53/5/1, k. 101-108, 110-114 22/53/10/1, k. 64-68, 117-119.

204 Sygn. 22/53/10/1, k. 88-105, 110-115, 222-223, 246-252.

205 Sygn. 22/53/5/1, k. 120-162, 228-229, 239-240.

206 Sygn. $22 / 53 / 6 / 1$, k. 2-15, 27-66, 77, 134-135; 22/53/10/1, k. 189-221.

207 Sygn. 22/53/6/2, k. 199-216.

208 Sygn. 22/53/10/2, k. 1-295.

209 Sygn. 22/53/7/1, k. 245, 246. 
połączenia kolejowego na Ukrainie Prawobrzeżnej; sprawozdania, dokumenty dotyczące składu kadr; wykazy sprzętów i transportów; dokumentacja finansowo-administracyjna ${ }^{210}$, a także papiery Departamentu Gospodarki Wodnej instrukcje, plan finansowo-gospodarczy ${ }^{211} \mathrm{i}$ inne.

Materiały związane z działalnością Zarządu Cywilnego SPP 212 to przede wszystkim korespondencja, głownie kierownika Zarządu J. Dobrotworskiego, jego rozporządzenia i wytyczne, m.in. wskazówki dla kierowników działów i poddziałów $\mathrm{SPP}^{213}$; sprawozdania i raporty, w tym sprawozdania $\mathrm{z}$ działalności za okres od 1 VII do 1 IX $1921 \mathrm{r}^{214}$; przeglądy prasy za $1921 \mathrm{r}^{215}$; projekt uniformu dla urzędników Zarządu Cywilnego przy SPP ${ }^{216} \mathrm{i}$ inne.

$Z$ dokumentów Biura Prasowo-Informacyjnego przy SPP, oprócz rozkazu o jego założeniu ${ }^{217}$, w omawianym zbiorze znajdują się sprawozdania tygodniowe i przeglądy prasy (z lipca, października, listopada 1921 r.) dotyczące organizacji powstania na Ukrainie ${ }^{218}$, a także raporty od różnych osób dla kierownika Biura M. Suchodolskiego-Peresady ${ }^{219}$ oraz jego raport dla jednego $\mathrm{z}$ dowódców SPP J. Otmarsztejna ${ }^{220}$.

W teczce o sygn. 22/53/6/1 są zgromadzone dokumenty dotyczące pogromów żydowskich na Ukrainie, które świadczą o tym, że rząd URL i dowództwo SPP zakazywało ich i potępiało te, które miały miejsce. Na ten niewielki zbiór składają się listy i kopie listów różnych osób, m.in. Serhija Diadiuszi, p.o. ministra spraw wojskowych URL, Andrija Nikowskiego, ministra spraw zagranicznych URL, W. Zelinskiego, kierownika Ukraińskiej Wojskowej Komisji Likwidacyjnej w RP do J. Tiutiunnyka oraz listy J. Tiutiunnyka do M. Omelanowycza-Pawłenki, ministra spraw wojskowych URL, i do A. Nikowskiego ${ }^{221}$. O współpracy SPP z organizacjami żydowskimi na Ukrainie świadczy m.in. „Schemat z zaznaczeniem żydowskich organizacji pomagających powstańcom w walce z Wielkorosją" przechowywany w Ossolineum ${ }^{222}$.

Cennym materiałem przedstawiającym działalność kulturową SPP na rzecz upamiętnienia wydarzeń ukraińskiego ruchu niepodległościowego,

210 Sygn. 22/53/7/1;22/53/7/2, k. 1-117. 22/53/10/1, k. 1-38.

211 Sygn. 22/53/7/1, k. 249-254.

212 Materiały te są umieszczone w różnych teczkach o sygn. 22/53/17/1, 22/53/17/2.

213 Sygn. 22/53/17/1, k. 115, 116 (2 egz.).

214 Tamże, k. 71-79.

215 Tamże, k. 84-149.

216 Sygn. 22/53/7/2, k. 118.

217 Zob. przyp. nr 172.

218 Sygn. 22/53/10/1, k. 61-63, 131-138, 152-184; sygn. 22/53/10/4, k. 18-32, 33-38.

219 Sygn. 22/53/10/1, k. 60, 71-73, 77-79, 84-85.

220 Tamże, k. 83.

221 Sygn. 22/53/6/1, k. 70, 75, 99-100, 104-108.

222 Tamże, k. 71. 
gromadzenia zbiorów i upowszechnienia wiedzy na ten temat, są dokumenty dotyczące założenia i działalności Muzeum Walki Wyzwoleńczej przy Sztabie Armii Powstańczej. W analizowanym zbiorze jest przechowywany rozkaz J. Tiutiunnyka dotyczący założenia Muzeum, wydany w październiku 1921 r. ${ }^{223}$, apel Muzeum do ukraińskich patriotów w sprawie zabytków narodowych ${ }^{224}$ oraz instrukcja dotycząca gromadzenia materiałów ${ }^{225}$.

W teczce o sygn. 22/53/7/2 zgromadzono dokumenty Ukraińskiej Narodowej Organizacji (dalej: UNO), założonej w celu wspierania ruchu partyzancko-powstańczego oraz tworzenia administracji cywilnej po wkroczeniu powstańców na Ukrainę. Omawiany zbiór zawiera bruliony i kopie odezw, rozkazów, instrukcji, wytycznych, raportów; schematy struktury organizacyjnej i regulaminy UNO; dokumenty związane z organizacją kursów przy UNO dla przygotowania kadr, w tym list prof. Iwana Szendryka do J. Tiutiunnyka, plan zajęć i inne ${ }^{226}$. Dokumenty te znajdują się w obwolucie z własnoręcznym zapisem J. Tiutiunnyka zaadresowanym do kierownika oddziału Departamentu Informacji Politycznej SPP Wołodymyra Łupenki-Łotockiego z prośbą o przepisanie materiałów ${ }^{227}$.

$\mathrm{W}$ teczkach z materiałami archiwum SPP przechowywanych w ZNiO znajdują się także dokumenty pochodzące $\mathrm{z}$ innych zbiorów. Są to m.in. kopie papierów związanych z polsko-ukraińskim porozumieniem $1919 \mathrm{r}^{228}$, w tym list Komendy Głównej Armii URL do Komendy Głównej Wojska Polskiego z 17 VII 1919; pełnomocnictwo od S. Petlury dla Petra Łypki, kierownika delegacji pokojowej URL w RP z 23 VII 1919; umowa o zawieszeniu broni między Wojskiem Polskim a Armią URL z 1 IX 1919 r. W teczce o sygn. 22/53/5/2 umieszczono „Statut Ukraińskiego Towarzystwa Wojskowego” (UWeT) ${ }^{229}$, założonego w $1921 \mathrm{r}$. przez ukraińskich żołnierzy internowanych w Polsce ${ }^{230}$. W teczce o sygn. 22/53/10/4 zgromadzono papiery Ludowego Komisariatu Spraw Wewnętrznych (NKWD) ZSRR z 1940 r., w tym rejestry poczty, kwity, potwierdzenia odbioru korespondencji ${ }^{231} \mathrm{itp}$. W teczce oznaczonej sygnaturą 22/53/17/3 przechowywano korespondencję Ukraińskiego Przeciwalkoholowego Towarzystwa „Відродження” 232 z lat 1935-1936 $6^{233}$.

223 Sygn. 22/53/17/1, k. 119-120.

224 Tamże, k. 117-118.

225 Tamże, k. 121-122.

226 Sygn. 22/53/7/2, k. 119-328.

227 Sygn. 22/53/10/1, k. 236.

228 Tamże, k. 230-233.

229 Sygn. 22/53/5/2, k. 24-25.

230 Р. Сушко, Хто вбив полковника Отмарштайна, Прага 1933, s. 7.

231 Sygn. 22/53/10/4, k. 80-114.

232 Więcej o towarzystwie zob. П. Шкарб'юк, ,Відродження”, [w:] Енциклопедія історії України : 10 m. Т. 1, редкол. В.А. Смолій (голова) та ін., Київ 2003, s. 533.

233 Sygn. 22/53/17/3, k. 258-267. 


\subsection{Archiwum Ołeksandra Kowałewskiego}

O. Kowałewskyj (1890 - po 1939) - minister prasy i propagandy (14 X 1920 - 24 III 1921, 5 VIII 1921 - 14 I 1922) oraz spraw rolnych (24 III 1921 14 I 1922) Rządu URL na emigracji w Tarnowie, jeden z założycieli i prezes Ukraińskiej Ludowo-Republikańskiej Partii (dalej: ULRP), przewodniczący Wołyńskiego Zjednoczenia Ukraińskiego działającego w Łucku w latach 1931-1939234.

Podobnie jak materiały redakcyjne „Červonej Kaliny”, archiwum O. Kowałewskiego wpłynęło do zbiorów biblioteki NTSz jako depozyt w latach 1939-1940 ${ }^{235}$. Przechowywany w Ossolineum zbiór ${ }^{236}$ zawiera różnorodne dokumenty związane głównie z działalnością Rady Republiki i Rady Ministrów URL, ukraińskich partii politycznych, przede wszystkim ULRP, oraz inne materiały dotyczące funkcjonowania Centrum Państwowego URL na wychodźstwie. Część dokumentów jest oznaczona inicjałami O. Kowałewskiego - O.K. oraz zapisem jego ręką „Мій архів” („Мój archiwum”).

Dużą część omawianego zbioru stanowi korespondencja służbowa oraz prywatna O. Kowałewskiego ${ }^{237}$, a także jego papiery osobiste - legitymacje, przepustki, zaświadczenia, zaproszenia, m.in. zaświadczenia o członkostwie w Ukraińskiej Misji Dyplomatycznej w RP z 21 X 1919 r. ${ }^{238}$ oraz w redakcji tygodnika „Воля” w Wiedniu z 7 V 1920 r. ${ }^{239}$; legitymacje p.o. dyrektora Kancelarii Ministerstwa Spraw Rolnych URL ${ }^{240}$, zastępcy przewodniczącego Towarzystwa Ukraińskiego Błękitnego Krzyża z 23 IX 1920 r. ${ }^{241}$, członka Rady Republiki URL z 25 I 1921 r. ${ }^{242}$; uprawnienie od Ukraińskiego Związku Narodowo-Państwowego w sprawie porozumienia z Wszechukraińską Radą Narodową w Kamieńcu ${ }^{243}$; wizytówka jako ministra spraw rolnych $\mathrm{URL}^{244} \mathrm{i}$ inne. $\mathrm{W}$ archiwum znajduje się również rozporządzenie Dyrektoriatu URL z 11 XII 1920 r. ${ }^{245}$ oraz zawiadomienie Sekretarza Stanu URL Mykoły Bahrynowskiego ${ }^{246}$ o po-

234 Р. Давидюк, Волинське Українське Об'єднання, [w:] Енциклопедія історії Украӥни : y 10 m. Т. 1, редкол. В.А. Смолій (голова) та ін., Київ 2003, s. 611.

235 Рукописні збірки, які потрапили як депозит..., s. 181-187 (poz. 22-24).

23610 teczek o sygn. 22/53/1/1-3, 22/53/9/1-3, 22/53/13/1-4.

237 Listy są umieszczone w różnych teczkach o sygn. 22/53/1/1-3, 22/53/9/2-3, 22/53/13/3-4.

238 Sygn. 22/53/1/1, k. 5.

239 Tamże, k. 55.

240 Tamże, k. 296.

241 Sygn. 22/53/1/2, k. 34 .

242 Sygn. 22/53/9/1, k. 104.

243 Sygn. 22/53/13/4, k. 241.

244 Sygn. 22/53/9/1, k. 93.

245 Sygn. 22/53/1/2, k. 78; 22/53/13/3, k. 140.

246 Sygn. 22/53/9/1, k. 233. 
wołaniu O. Kowałewskiego na urząd Ministra Prasy i Propagandy z załączonym wyciągiem z posiedzenia Rady Ministrów URL z 10 VIII $1921 \mathrm{r}^{247}$

W omawianym zasobie są przechowywane teksty artykułów, przemówień, referatów O. Kowałewskiego, głównie bruliony i kopie, m.in.: „Криза української інтелігенції”, „Між двох стільців”, „Три роки”, „Українська справа за кордоном”, „Наші завдання” ${ }^{248}$, „Боротьба за державність боротьба за право”249, „В ставці Головного Отамана. (Вражіння)” - relacje z podróży do sztabu Atamana S. Petlury ${ }^{250}$ i inne. Oprócz tego zbiór zawiera zaproszenia dla O. Kowałewskiego na spotkania, m.in. z Naczelnym Atamanem S. Petlurą 251 , a także na różne, głównie kulturalne, wydarzenia, m.in. na uroczystość z okazji 60. rocznicy śmierci T. Szewczenki organizowaną w obozie dla internowanych w Łańcucie, koncert Komitetu Zapomogowego dla Uchodźców z Ukrainy ${ }^{252}$, imprezy literackie zorganizowane przez Towarzystwo Literacko-Artystyczne „Сонцесвіт”, wieczory-akademie organizowane w Tarnowie z okazji rocznic śmierci hetmana Iwana Mazepy oraz T. Szewczenki ${ }^{253} \mathrm{i}$ inne. W archiwum znajdują się także afisze $\mathrm{z}$ informacją o wykładach O. Kowałewskiego w Urzędzie Miejskim Kijowa 17 V 1920 r. oraz w Częstochowie 26 II 1921 r. ${ }^{254}$

Osobną grupę stanowią materiały, głównie kopie i bruliony, dotyczące konfliktu między O. Kowałewskim a gen. Wiktorem Pawłenkiem, ministrem spraw wojskowych URL ${ }^{255}$. Zbiór zawiera m.in. listy O. Kowałewskiego do W. Pawłenki ${ }^{256}$ oraz do Kłyma Pawluka, konsula URL w Wolnym Mieście Gdańsku ${ }^{257}$, a także protokół z badań lekarskich O. Kowałewskiego ${ }^{258}$.

W analizowanym zasobie archiwum NTSz są przechowywane materiały dotyczące działalności Rady Ministrów URL. Zbiór zawiera m.in. Uchwałę o dymisji rządu Andrija Liwyckiego z 24 III 1921 r. ${ }^{259}$ oraz Rozporządzenie S. Petlury z 28 III 1921 r. o powołaniu nowego rządu pod kierownictwem

247 Tamże, 234.

248 Sygn. 22/53/1/1, k. 16-19, 102-105, 300-306, 328-331.

249 Sygn. 22/53/13/3, k. 159-161.

250 Sygn. $22 / 53 / 13 / 3$, k. $169-173 ; 22 / 53 / 13 / 4$, k. 232-236.

251 Sygn. 22/53/9/1, k. 94, 99, 226, 227, 251, 259; 22/53/9/2, k. 22; 22/53/13/3, k. 199 .

252 Sygn. 22/53/9/1, k. 105, 224-225.

253 Sygn. 22/53/9/2, k. 56, 89, 196-198.

254 Sygn. 22/53/1/1, k. 4, 298.

255 Więcej o konflikcie, m.in. na podstawie dokumentów ze zbiorów ZNiO, zob. I. Срібняк, Генерал В. Павленко vs міністра О. Ковалевського..., s. 40-45.

256 Sygn. 22/53/9/2, k. 93-94, 96-97, 99-100 (3 kopie maszynopisu).

257 Tamże, k. 101-102.

258 Tamże, k. 95, 98.

259 Sygn. 22/53/1/1, k. 20. 
Wiaczesława Prokopowycza ${ }^{260}$; materiały z posiedzeń Rady Ministrów URL z 26 III i 2 IV 1921 r. ${ }^{261}$; odezwę do ludności ukraińskiej w sprawie przygotowania powstania przeciw bolszewikom ${ }^{262}$; „Projekt Ustawy o Obywatelstwie URL”"263; ,Statut Ekspozytury Rządu URL przy Rządzie RP w Warszawie”264 oraz inne dokumenty.

W omawianym zbiorze są przechowywane dokumenty, głównie kopie, przedstawiające działalność poszczególnych gabinetów rządowych URL, przede wszystkim Ministerstwa Prasy i Propagandy (dalej: MPiP). Są to m.in.: sprawozdania z działalności MPiP ${ }^{265}$ oraz sprawozdanie z działalności Działu Prasy i Informacji MPiP za luty 1921 r. ${ }^{266}$; raport MPiP w sprawie obniżenia jego kosztorysu przez Komisję Finansową ${ }^{267}$; instrukcja dla Działu Prasy MPiP z 1 II 1921 r. ${ }^{268}$; egzemplarze wydań MPiP: „Огляд Преси” z 6 III 1921 r. oraz „Обіжник” („Okólnik”) Ukraińskiego Biura Prasowego („Ukrainpresu") z 7 i 16 III 1921 r. ${ }^{269}$; Postanowienie Prezesa Rady Ministrów URL o dofinansowaniu MPiP ${ }^{270}$; lista wydawnictw dofinansowanych ze środków MPiP do 1 VII $1920 \mathrm{r}^{271}$. Bardzo cenne informacje na temat pobytu ukraińskich żołnierzy i jeńców w obozach dla internowanych zawierają raporty i sprawozdania z wizytacji, przygotowane dla MPiP. Raporty z lat 1920-1921 zawierają dane o obozach w Kaliszu, Częstochowie, Pikulicach, Łańcucie oraz Aleksandrowie ${ }^{272}$.

W archiwum są także przechowywane kopie sprawozdań i raportów z działalności Ministerstwa Spraw Rolnych ${ }^{273}$, Ministerstwa Spraw Wojskowych ${ }^{274}$, Ministerstwa Spraw Zagranicznych, w tym Misji Dyplomatycznych URL, m.in.: komunikaty i biuletyny dotyczące powstania na Ukrainie pod dowództwem J. Tiutiunnyka ${ }^{275}$, raporty Konsulatów URL w Niemczech i Wiedniu

260 Sygn. $22 / 53 / 13 / 3$, k. 341 .

261 Sygn. 22/53/1/1, k. 21, 40.

262 Sygn. 22/53/9/1, k. 74-76.

263 Sygn. 22/53/13/3, k. 335-336.

264 Tamże, k. 339-340.

265 Sygn. 22/53/1/1, k. 23-26; 22/53/9/2, k. 29-40, 175-181.

266 Sygn. 22/53/13/3, k. 314-318.

267 Sygn. 22/53/1/1, k. 132-135.

268 Tamże, k. 28.

269 Tamże, k. 31-35, 157.

270 Sygn. 22/53/13/3, k. 308.

271 Tamże, k. 329.

272 Sygn. 22/53/1/1, k. 112-131. Więcej o treści tych dokumentów zob. I. Sribnyak, Historia utrwalona w dokumentach..., s. 158-160.

273 Sygn. 22/53/9/2, k. 17-21.

274 Tamże, k. 59-60.

275 Tamże, k. 72-75, 112-113, 125-127, 139, 171-174. 
oraz Misji Dyplomatycznej w Budapeszcie ${ }^{276}$. Zbiór zawiera także materiały, głównie kopie, dotyczące działalności Komisji Handlowej (KH) URL za granicą z lat 1919-1923, w tym protokoły rewizji; spisy pracowników; raporty, m.in. Ołeksandra Żukowskiego, kontrolera misji wojskowych URL za granicą; sprawozdania finansowe; rozporządzenie S. Petlury o przekazaniu wszystkich kredytów, majątku i dokumentacji finansowej Ambasady URL w Niemczech KH URL za granicą ${ }^{277}$; uprawnienie dla KH do prowadzenia zakupów zagranicznych w imieniu Ministerstwa Gospodarki URL ${ }^{278} \mathrm{i}$ inne.

Z materiałów związanych z działalnością Rady Republiki, czyli parlamentu emigracyjnego URL, w omawianej części archiwum znajdują się kopie dokumentów dotyczących jej tworzenia, m.in. sprawozdanie z działalności Międzypartyjnego Biura i Narady Ukraińskich Partii w okresie od 7 XII 1920 do 11 I 1921 r. w sprawie powołania Rady Republiki ${ }^{279}$ oraz protokół z otwarcia Rady Republiki URL z 3 II 1921 r. ${ }^{280}$, Regulamin Rady Republiki z 30 III 1921 r. (druk) ${ }^{281}$ oraz wycinek artykułu pt. Привітання Раді Республіки ${ }^{282}$. W omawianym zbiorze są także przechowywane kopie protokołów z posiedzeń i plenów Rady Republiki URL z 12 II - 4 III 1921 r. ${ }^{283}$ i 9 III - 4 IV 1921 r. ${ }^{284}$ oraz z posiedzeń Konwentu Seniorów Rady Republiki URL ${ }^{285}$; kopie uchwał i ustaw, m.in. Uchwała XXIV Plenum Rady Republiki dotycząca polityki finansowo-gospodarczej Rządu URL ${ }^{286}$, Ustawa o nadaniu ziemi kozakom, starszynom i urzędnikom wojskowym Armii URL, Ustawa o redukcji etatów i niektórych instytucji państwowych oraz o świadczeniach pieniężnych dla zwolnionych pracowników ${ }^{287}$, odezwy i uniwersały do ludności ukraińskiej z 12 III i 22 VI 1921 r. ${ }^{288}$

Ze względu na to, że O. Kowałewskyj był członkiem Centralnego Komitetu Ukraińskiej Ludowo-Republikańskiej Partii, wśród materiałów w omawianym zespole są przechowywane dokumenty związane z działalnością ULRP, w tym przede wszystkim liczna korespondencja członków partii ${ }^{289}$, a także deklaracje

276 Tamże, k. 45, 108, 114-116, 121-122, 128.

277 Sygn. 22/53/1/1, k. 276-294.

278 Sygn. 22/53/13/3, k. 321.

279 Tamże, k. 111-112.

280 Tamże, k. 3-34.

281 Sygn. 22/53/13/4, k. 226-229.

282 Sygn. 22/53/13/2, k. 249.

283 Sygn. 22/53/13/1, k. 104-246

284 Sygn. 22/53/13/2, k. 1-221.

285 Sygn. 22/53/13/2, k. 222-224; 22/53/13/1, k. 4-98.

286 Sygn. 22/53/13/3, k. 303.

287 Tamże, k. 337-338, 342.

288 Sygn. 22/53/13/2, k. 248 22/53/13/4, k. 222.

289 Korespondencja jest rozproszona w teczkach o sygn. 22/53/1/1-3, 22/53/9/1-3, $22 / 53 / 13 / 1-4$. 
o wstąpieniu i wystąpieniu z partii ${ }^{290}$; kopie rezolucji, wyciągów i protokołów z posiedzeń CK ULRP ${ }^{291}$; materiały II i III Konferencji ULRP w Tarnowie ${ }^{292}$; papiery dotyczące działalności ULRP w Radzie Republiki, m.in.: podania do Prezesa Rady Ministrów URL w sprawie pomocy finansowej dla Ołeksandra Baziłewycza ${ }^{293}$ oraz w sprawie czasopisma „Volâ" ${ }^{294}$, apele i podania posłów Rady Republiki do frakcji ULRP w sprawie redukcji ministerstw URL ${ }^{295}$, apel ministra spraw wewnętrznych URL Mychajła Bilinskiego do Prezydium ULRP w sprawie wyznaczenia delegatów do Rady Republiki z 1 VIII 1921 r. ${ }^{296}$, gratulacje dla Ludowo-Republikańskiej frakcji od jej członków z okazji uczestnictwa w Radzie Republiki ${ }^{297}$, a także sprawozdania i raporty ULRP, m.in. raport za lata 1918-1920 pt. „За два роки”298.

W omawianej części archiwum znajdują się także materiały, głównie kopie i bruliony, dotyczące polsko-ukraińskiego porozumienia w latach 1919-1920. Są to m.in. dokumenty w języku francuskim - np. „Memorandum présenté au Gouvernement Polonais par la Colonie Ukrainienne à Varsovie” oraz „Projet d'articles principaux de l'accord polonais-ukrainien"299, a także materiały z posiedzenia międzypartyjnego w Warszawie 2 XII 1919 r., w tym Deklaracja Centralnych Komitetów Ukraińskich Partii Demokratycznych ${ }^{300}$ - ULRP, $\mathrm{UPSN}^{301}, \mathrm{UPDW}^{302}$, tekst przemówienia O. Kowałewskiego ${ }^{303}$ oraz „Memoriał członków trzech Demokratycznych Partii Ukraińskich do Józefa Piłsudskiego" ${ }^{304}$. W tejże teczce o sygn. 22/53/1/2 znajdują się dokumenty dotyczące sytuacji Ukraińców na ziemiach Chełmszczyzny, Podlasia i Polesia, przygotowane i wysłane do O. Kowałewskiego przez Tymosza Ołesiuka, komisarza do spraw oświaty powiatu chełmskiego ${ }^{305}$.

Analizowany zasób zawiera także materiały, głównie kopie, dotyczące porozumienia między rządem URL a Rosyjskim Komitetem Politycznym (dalej:

290 Sygn. 22/53/1/1, k. 313; 22/53/1/3, k. 30-69, 72-73; 22/53/13/3, k. 84, $150 \mathrm{i}$ inne.

291 Materiały są rozproszona w teczkach o sygn. sygn. 22/53/1/1-3, 22/53/9/1-3, 22/53/13/1-4

292 Sygn. 22/53/1/3, k. 1-12, 15-29, 142-146, 158-189; 22/53/9/1, k. 55-68, 279-317;

$22 / 53 / 13 / 1$, k. 1-2; 22/53/13/3, k. 55-56, 186-302; 22/53/13/4, k. 1-38, 43-54, 96-100 i inne.

293 Sygn. 22/53/13/3, k. 60.

294 Tamże, k. 61.

295 Tamże, k. 116-122.

296 Tamże, k. 123.

297 Tamże, k. 162.

298 Tamże, k. 35-54.

299 Sygn. 22/53/1/2, k. 1-7.

300 Tamże, k. 9-10.

301 Ukraińska Partia Socjalistów-Niepodległościowców.

302 Ukraińska Partia Demokratyczno-Włościańska.

303 Sygn. 22/53/1/2, k. 11-13.

304 Tamże, k. 56-57.

305 Tamże, k. 14-50. 
RKP) w Warszawie. Na ten zbiór składają się m.in protokoły z posiedzeń delegacji rządu URL ${ }^{306}$ oraz protokoły z rokowań pomiędzy delegacją rządu URL oraz przedstawicielami RKP ${ }^{307}$; uprawnienia do udziału w rokowaniach dla Pawła Zajcewa, Leonida Mychajłowa, Stanisława Stempowskiego, Ottona Eichelmanna, O. Kowałewskiego ${ }^{308}$; projekt konwencji pomiędzy URL a RKP opracowany przez gen. W. Zelinskiego ${ }^{309}$; instrukcja Ministra Spraw Zewnętrznych A. Nikowskiego dla przedstawicieli rządu URL w sprawie rokowań z RKP ${ }^{310}$; konwencja wojskowa między RKP a Rządem URL z 18 XI 1920 r. ${ }^{311}$; deklaracja o uznaniu przez przewodniczącego RKP Borisa Sawinkowa władzy gen. Piotra Wrangla i telegram tego ostatniego w tej samej sprawie $^{312} \mathrm{i}$ inne.

Jako członek Towarzystwa Ukraińskiego Błękitnego Krzyża O. Kowałewskyj przechowywał w swoim archiwum dokumenty związane z działalnością stowarzyszenia. W ossolińskiej części zasobu znajduje się m.in. kopia „Statutu” Towarzystwa ${ }^{313}$, nieliczna korespondencja, a także uprawnienia i zaświadczenia O. Kowałewskiego ${ }^{314}$.

Oprócz dokumentów emigracyjnego Centrum Państwowego URL, w analizowanej części archiwum znajdują się materiały związane z działalnością różnych politycznych ugrupowań - rad i sojuszów - stworzonych przez ukraińskie partie w celu wsparcia lub przeciwstawienia się władzom URL. Między innymi w teczce o sygn. 22/53/1/2 są przechowywane materiały, głównie bruliony i kopie, dotyczące Ukraińskiej Rady Narodowej, stworzonej w Kamieńcu 11 I 1920 r. w celu wspierania rządu URL przez przedstawicieli ukraińskich partii politycznych oraz przez instytucje samorządowe, społeczne, kulturowe i naukowe ${ }^{315}$. W teczce o sygn. 22/53/1/1 znajduje się protokół z posiedzenia pierwszej sesji Wszechukraińskiej Rady Narodowej założonej w Wiedniu na początku 1921 r. z inicjatywy Ukraińskiej Partii Socjalistów-Federalistów ${ }^{316}$.

306 Sygn. 22/53/1/1, k. 217-229.

307 Tamże, k. 230-259, 265-268.

308 Tamże, k. 213-216, 272.

309 Tamże, k. 260-264.

310 Tamże, k. 269, 308.

311 Sygn. 22/53/13/3, k. 343-350.

312 Sygn. 22/53/1/1, k. 271 .

313 Sygn. 22/53/1/2, k. 61-70.

314 Sygn. 22/53/1/1, k. 41;22/53/1/2, k. 71;22/53/9/1, k. 34, 136-137.

315 Sygn. 22/53/1/2, k. 51-55, 58-59, 73-77. Więcej o działalności URN zob. О. Павлишин, Українська Національна Рада в Кам'яниі на Поділлі (1920), [w:] Проблеми вивчення історії Української революцї̈ 1917-1921 років : Збірник наукових статей. Вип. 11, Київ 2015, s. 118-137.

316 Sygn. 22/53/1/1, k. 165-167. 


\subsection{Archiwum Ostapa Łuckiego}

Ostap (Stanisław) ${ }^{317}$ Łuckyj (1883-1941) - działacz ukraiński; wojskowy w czasie I wojny światowej oficer armii austriackiej, adiutant arcyksięcia Wilhelma Habsburga, od 1918 żołnierz w armii ukraińskiej (w Legionie Ukraińskich Strzelców Siczowych oraz UHA), w 1920 przedstawiciel Armii URL w sztabie Wojska Polskiego; pisarz i publicysta; polityk - poseł na Sejm II RP II i III kadencji, senator II RP IV i V kadencji; działacz społeczny i państwowy, organizator i propagator ukraińskiego ruchu spółdzielczego i gospodarczego w Galicji w latach 20. i 30. XX w. Od 1928 r. do początku II wojny światowej pełnił funkcję przewodniczącego zarządu Związku Rewizyjnego Spółdzielni Ukraińskich (dalej: ZRSU), który obejmował największe ukraińskie centrale spółdzielcze oraz prowadził szeroką działalność kulturalno-oświatową i szkoleniową ${ }^{318}$. Jako działacz polityczny O. Łuckyj należał do Centralnego Komitetu Ukraińskiego Zjednoczenia Narodowo-Demokratycznego - największej ukraińskiej partii politycznej w II RP, był jednym z twórców i najbardziej aktywnych uczestników Ukraińskiej Reprezentacji Parlamentarnej (dalej: URP $)^{319}$ - najsilniejszej formacji prezentującej ukraiński ruch niepodległościowy w Galicji pierwszej połowy XX w. ${ }^{320}$

Archiwum zgromadzone w ośmiu teczkach ${ }^{321}$ zawiera papiery służbowe i prywatne O. Łuckiego i jego rodziny, dokumenty związane z działalnością URP w Sejmie i Senacie RP, materiały dotyczące gospodarki i ukraińskiego ruchu spółdzielczego w Galicji z pierwszej połowy XX w. i inne.

$\mathrm{Z}$ papierów osobistych $\mathrm{w}$ omawianym zasobie znajdują się dokumenty członków rodziny Łuckich, m.in. świadectwa szkolne z lat 1929-1937 oraz karta wpisowa ucznia należące do syna O. Łuckiego, Jerzego ${ }^{322}$, a także świadectwa szkolne z lat 1926-1932, życiorys, świadectwo moralności i wykaz ocen córki Marty ${ }^{323}$. W teczce o sygn. 22/53/8/2 są zgromadzone papiery

317 Dokumenty w języku polskim Łuckyj podpisywał imieniem Stanisław.

318 ZRSU obejmował m.in.: Towarzystwo Ubezpieczeń Wzajemnych „Dnìster”, Centralny Bank Spółdzielczy „Krajowy Związek Kredytowy”, Krajowy Związek Mleczarski „Masłosojuz”, Związek Związków Spółdzielczych „Centrosojuz” i spółdzielnie spożywców w miastach „Narodna Torhiwla”, zob. S. Wrzosek, Związek Rewizyjny Spótdzielni Ukraińskich we Lwowie, [w:] Encyklopedia historii gospodarczej Polski do 1945. T. 2, Warszawa 1981, s. 564.

319 W dokumentacji parlamentarnej występowały dwa odrębne kluby: Klub Ukraiński w Sejmie i Klub Ukraiński w Senacie Więcej na ten temat zob. M. Szumiło, Ukraińska reprezentacja parlamentarna w Sejmie i Senacie RP (1928-1939), Warszawa 2007, s. 54.

320 Tamże.

321 Sygn. 22/53/8/1-3, 2253/14/1-3, 22/53/15, 22/53/16.

322 Sygn. 22/53/8/1, k. 7-8, 9-27, 86-93.

323 Tamże, k. 70-85. 
żony O. Łuckiego, Ireny, dotyczące prowadzenia gospodarstwa domowego ${ }^{324}$. W teczce o sygn. 22/53/8/3 znajduje się życiorys Mychajła Wadiuka-Łuckiego, ojca O. Łuckiego ${ }^{325}$, konspekt dotyczący rolnictwa, uprawy roślin i gleby, przygotowany przez brata O. Łuckiego, Myrona ${ }^{326}$ oraz książka wydatków domowych z lat 1921-1924 samego O. Łuckiego ${ }^{327}$. W teczce o sygn. 22/53/8/1 jest zawarta nieliczna korespondencja rodzinna Łuckich ${ }^{328}$.

W teczce o sygn. 22/53/8/1 są przechowywane autografy dzieł literackich O. Łuckiego, a mianowicie niewydany do dzisiaj zbiór jego przekładów poetyckich z lat 1920-1921 pt. „Ex libris”329, który zawiera tłumaczenia na język ukraiński wierszy różnych autorów, m.in. Walta Whitmana, Jaroslava Vrchlickiego (wł. Emila Fridy), Otokara Březiny, Josefa Svatopluka Machara ${ }^{330}$, Konstantina Balmonta, Tadeusza Micińskiego, Alfreda Momberta. W tejże teczce znajdują się również bruliony i maszynopisy dzieł i innych przekładów O. Łuckiego, wycinki z druków, a także maszynopisy z wierszami Charlesa Baudelaire'a w języku francuskim ${ }^{331}$.

Dużą cześć materiałów służbowych O. Łuckiego stanowi korespondencja związana z jego działalnością gospodarczą i polityczną ${ }^{332}$. Wśród papierów w ossolińskiej części archiwum NTSz znajdują się także teksty jego referatów i artykułów, m.in. brulion referatu przygotowanego na XV Międzynarodowy Kongres Rolniczy pt. „Резюме докладів про освіту і виховання в сіл[ьсько]госп[одарській] кооперації поодиноких країн"333, maszynopisy artykułów „Кооперація і приватники” oraz „Кооперація і капіталістичні (приватні) підприємства" ${ }^{334}$. W omawianym zbiorze są przechowywane teksty innych autorów na temat gospodarki i ruchu spółdzielczego, m.in. Pawła Panczenki ${ }^{335}$, Karła Koberskiego ${ }^{336}$, Mykoły Kapusty ${ }^{337}$, Wiktora Domanyckiego ${ }^{338}$.

324 Sygn. 22/53/8/2, zesz. II-V.

325 Sygn. 22/53/8/3, zesz. I, k. 75-174.

326 Tamże, zesz. III, k. 175-249.

327 Tamże, zesz. II, k. 256-317.

328 Sygn. 22/53/8/1, k. 35-57.

329 Tamże, k. 321-355.

330 Więcej o przekładach O. Łuckiego z poezji czeskiej umieszczonych w zbiorze „Ex libris” zob. В. Моторний, А. Моторний, О. Медовніков, Невідомі та забуті переклади О. Луцького з чеської модерної поезї̈, [w:] Муза і чин Остапа Луцького, Київ 2016, s. 628-648.

331 Sygn. 22/53/8/1, k. 356-397.

332 Korespondencja jest rozproszona w teczkach o sygn. 22/53/8/1, 2253/14/1-3, 22/53/15, 22/53/16.

333 Sygn. 22/53/14/1, k. $147-158$.

334 Sygn. 22/53/14/3, k. 131-169, 170-180.

335 Tamże, k. 1-21.

336 Tamże, k. 213-216.

337 Sygn. 22/53/14/2, k. 281-283.

338 Tamże, k. 284-285. 
Z materiałów dotyczących spółdzielczości ukraińskiej w latach 20. i 30. $\mathrm{XX}$ w., oprócz korespondencji, są przechowywane papiery, głównie kopie i bruliony, związane z działalnością ZRSU, m.in. „Projekt statutu”339; obwieszczenia i raporty z posiedzeń z 1932 r. ${ }^{340}$; dokumenty sprawozdawcze ZRSU z lat 19251939 , m.in. sprawozdania finansowe spółdzielni „Masłosojusz” za $1931 \mathrm{r}^{341}$ oraz Centralnego Banku Spółdzielczego „Krajowy Związek Kredytowy” za 1931 r. i za październik-listopad $1932 \mathrm{r}^{342}$, dane i zestawienia statystyczne oraz finansowe dotyczące działalności powiatowych ośrodków ZRSU z lat 1937-1938 ${ }^{343}$, wykaz producentów należących do ZRSU i zestawienie ich obrotów gospodarczych z lat 1935-1939 ${ }^{344}$, sprawozdania z działalności ZRSU i jego Wydziałów, m.in. Rewizyjnego i Organizacyjnego, z lat $1937-1938^{345}$, zestawienia finansowe i statystyczne zasobów spółdzielni handlowych z lat 1937-1938 34 , dokumenty sprawozdawcze spółdzielni kredytowych oraz Powiatowych Sojuszy Kooperatyw ZRSU z lat 1920-1931 ${ }^{347}$. Zbiór zawiera także materiały Zebrania Ogólnego ZRSU, m.in. kopie dezyderatów i rezolucji, wykaz referentów, protokół z posiedzenia, listę wyróżnionych spółdzielni ukraińskich z lat 1937-1938 348 ; materiały VII Krajowego Zjazdu Spółdzielczego (dalej: KZS) we Lwowie 29 VI 1932 r., w tym regulamin KZS, protokoły z posiedzeń Komisji, dezyderat do Rady ZRSU, projekty i uwagi do projektów rezolucji dotyczących ZRSU, „Centrosojuszu”, „Masłosojuszu” i innych spółdzielni kredytowych ${ }^{349}$.

W teczce o sygn. 22/53/15 są zgromadzone papiery związane z działalnością Centralnego Banku Spółdzielczego „Krajowy Związek Kredytowy” (Centrobank „KZK”) we Lwowie z lat 1920-1930, w tym materiały dotyczące ukraińskich funduszy pożyczkowych i kredytów bankowych oraz papiery dotyczące współpracy Centrobanku „KZK” z Österreichische Kommunalbank w Wiedniu. W tejże teczce znajdują się dokumenty dotyczące porozumienia o współpracy między spółdzielniami Ukrainy Zachodniej i Radzieckiej ${ }^{350}$, a także materiały związane z finansowaniem czasopisma „Розбудова Націï” - organu prasowego Zarządu Ukraińskich Nacjonalistów ${ }^{351}$.

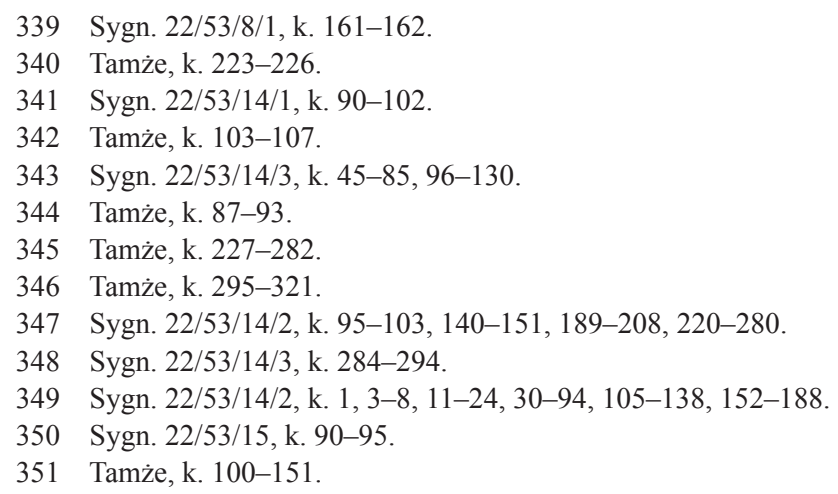


Osobną grupę dokumentów w omawianym zbiorze stanowią papiery związane z działalnością oświatowo-edukacyjną ZRSU. Są to sprawozdania z działalności za lata 1921-1933 oraz oferta edukacyjna ZRSU ${ }^{352}$, zestawienie statystyczne za rok 1937 dotyczące udziału w kursach edukacyjnych organizowanych przez ZRSU ${ }^{353}$, a także materiały związane z działalnością Szkoły Handlowej Towarzystwa „Просвіта” we Lwowie, którą ZRSU wspierał finansowo, w tym programy nauczania, preliminarz i dane budżetowe, listy dyrektora szkoły Denysa Korencia do różnych osób i instytucji ${ }^{354} \mathrm{i}$ inne.

Wśród materiałów związanych z działalnością polityczną O. Łuckiego jako posła na Sejm RP i członka URP w omawianym zbiorze są m.in. przechowywane: „Правильник Української Парламентарної Репрезентації”, czyli regulamin URP ${ }^{355}$; kopie i bruliony przemówień O. Łuckiego, m.in. na posiedzeniu Komisji Budżetowej Ministerstwa Spraw Rolnych RP oraz w Sejmie RP ${ }^{356}$; interpelacje posłów URP do Ministrów Spraw Wewnętrznych oraz Przemysłu i Handlu RP w sprawach bezprawnego unieruchomienia przedsiębiorstw handlowych i przemysłowych spółdzielni ukraińskich oraz nadużyć polskich urzędników ${ }^{357}$ i inne. W teczce o sygn. 22/53/8/1 znajdują się dokumenty, głównie kopie i bruliony listów, dotyczące założenia Ukraińskiego Towarzystwa Przyjaciół Ligi Narodów ${ }^{358}$. Teczka o sygn. 22/53/16 zawiera papiery zawiązane z petycją URP zgłoszoną do Ligi Narodów w sprawie pacyfikacji Galicji Wschodniej w 1930 r. ${ }^{359}$ i inne.

\subsection{Materiały różne}

W dwóch teczkach o sygn. 22/53/11/1 i 22/53/11/2 są zgromadzone papiery Nazara Hnatiuka ${ }^{360}$, dziennikarza i publicysty, nauczyciela, członka ULRP, urzędnika MPiP URL. Zbiór zawiera dzienniki N. Hnatiuka za okres 6 VII 23 XII 1921 r. oraz różne dokumenty związane z jego działalnością partyjną, dziennikarską i z pracą w MPiP URL ${ }^{361}$.

352 Sygn. 22/53/14/1, k. 108-114.

353 Sygn. 22/53/14/3, k. 94-95.

354 Sygn. 22/53/8/1, k. 134-137; 153-155; 22/53/14/1, k. 115-122.

355 Sygn. 22/53/14/1, k. 59-61.

356 Tamże, k. 2-10, 20-30, 62-74.

357 Tamże, k. 11-19; 22/53/16, k. 136-140, 151.

358 Sygn. 22/53/8/1, k. 163, 166-167, 200-204, 214, 217.

359 Sygn. 22/53/16, k. 109-135.

360 Papiery N. Hnatiuka, jak i opisane poniżej dokumenty W. Sklara i H. Denysenki, do biblioteki NTSz trafiły jako depozyt w latach 1939-1940, zob. Рукописні збірки, які потрапили як депозит..., s. 181-187 (poz. 11-13).

361 Zawartość teczek z papierami N. Hnatiuka szczegółowo opisała w artykułach L. Snicarczuk, zob. Л. Сніцарчук, „Тарнів. Емігращіяя. 1921 рік”: Щоденникові записи журналіста 
W kolejnych dwóch teczkach o sygn. 22/53/3 i 22/53/4 są przechowywane papiery Wasyla Sklara, żołnierza Armii URL, Komisarza Przyfrontowego przy 4 Kijowskiej Dywizji Strzelców, wywiadowcy SPP. W omawianym zbiorze zawarta jest korespondencja W. Sklara, a także jego dokumenty osobiste, m.in. zaświadczenia Ukraińskiej Komisji Likwidacyjnej w Warszawie ${ }^{362}$, Sztabu Partyzancko-Powstańczego ${ }^{363}$, Ministerstwa Spraw Wewnętrznych URL ${ }^{364}$; legitymacje i zaświadczenia Komisarza Przyfrontowego ${ }^{365}$, w tym zaświadczenie o zwolnieniu ze stanowiska z 11 XII $1920 \mathrm{r}^{366}$, a także dokumentacja finansowa Komisji Przyfrontowej przy 4. Kijowskiej Dywizji Strzelców Armii URL ${ }^{367}$, prowadzona przez Sklara ${ }^{368} \mathrm{i}$ inne. W teczce o sygn. 22/53/3 znajdują się również materiały związane z działalnością Ołeksandra Krasowskiego, żołnierza Armii URL, członka Ukraińskiej Socjaldemokratycznej Partii Robotniczej, urzędnika Ministerstwa Gospodarki Narodowej URL. Są to dokumenty osobiste, m.in. paszport rosyjski, legitymacje i zaświadczenia, a także korespondencja służbowa $^{369}$. Teczka o sygn. 22/53/4 oprócz papierów W. Sklara zawiera papiery Frontu Jedności Narodowej z lat 1936-1937, w tym statut i regulamin partii, sprawozdania i protokoły z posiedzeń, materiały I Kongresu FJN oraz korespondencja ${ }^{370}$.

W teczce o sygn. 22/53/12 są zgromadzone papiery Hryhorija Denysenki związane z jego działalnością jako Wojskowego Komisarza Przyfrontowego Armii URL, współzałożyciela Ukraińskiego Towarzystwa Pomocy Emigrantom z Wielkiej Ukrainy oraz członka Ukraińskiej Partii Socjalistów-Rewolucjonistów $w^{371}$.

W archiwum NTSz przechowywanym w Ossolineum, znajduje się również rękopiśmienny egzemplarz „ВБстника” za rok $1890^{372}$, pisma Internatu Ruskiego XX. Zmartwychwstańców we Lwowie założonego przez polskiego

Назара Гнатюка, „Збірник Праць Науково-дослідного Інституту Пресознавства” 2014, вип. 4, s. 559-573; tejże, Назар Гнатюк: „Бути журналістами в тяжкий для пресової праці час” (1917-1921), „Образ” 2017, вип. 3, s. 78-87; tejże, „Організація дійсної і доиільної пропаганди за кордоном”: міністерство преси $і$ пропаганди УНР у 1921 p., „Вісник Львівського Університету. Серія Журналістика" 2015, вип. 40, s. 144-155.

362 Sygn. 22/53/3, k. 16.

363 Tamże, k. 82.

364 Sygn. 22/53/4, k. 84 .

365 Tamże, k. 67, 72, 91, 92.

366 Tamże, k. 367.

367 Tamże, k. 1-39.

368 Więcej o papierach W. Sklara w archiwum NTSz ze zbiorów Ossolineum zob. I. Sribnyak, Historia utrwalona $w$ dokumentach..., s. 160.

369 Sygn. 22/53/3. Opisując zawartość teczki I. Sribniak błędnie przypisał znajdujące się w niej dokumenty O. Kowałewskiemu, zob. I. Sribnyak, Historia utrwalona w dokumentach..., s. 160.

370 Sygn. 22/53/4, k. 124-166, 170-341.

371 Sygn. 22/53/12, k. 1-291.

372 Sygn. 22/53/19, $25 \mathrm{k}$. 
duchownego i historyka Waleriana Kalinkę dla wychowania ukraińskiej młodzieży, przede wszystkim grekokatolików ${ }^{373}$.

\section{Podsumowanie}

W wyniku działań wojennych i zmiany mapy politycznej Europy w pierwszej połowie XX w. duża część polskich oraz ukraińskich dóbr kultury uległa zniszczeniu lub przemieszczeniu. Materiały z ukraińskiego archiwum NTSz wywiezione ze Lwowa przez władze niemieckie razem z polskimi zbiorami bibliotecznymi na początku 1944 r. znalazły się w Polsce i zostały podzielone między dwie instytucje: BN w Warszawie i ZNiO we Wrocławiu.

Mimo że negocjacje polsko-ukraińskie w sprawie rewindykacji z Polski fragmentów archiwum NTSz w zamian na pozostałe we Lwowie zbiory Ossolineum nie doszły do skutku, obu stronom udało się znaleźć efektywne rozwiązanie. Umowa podpisana w 2003 r. między Ossolineum a LNNBU im. W. Stefanyka nadała każdej z instytucji pełny dostęp do swoich zbiorów (do poloników we Lwowie i do ukrainików we Wrocławiu) oraz pozwoliła na ich kopiowanie i opracowanie.

Zasób archiwalny NTSz przechowywany w Ossolineum to zespół różnorodnych dokumentów pochodzących z kilku archiwów i zbiorów. W archiwum spółdzielni wydawniczej „Červona Kalina” znajdują się materiały dotyczące historii ukraińskiego ruchu wyzwoleńczego lat 1917-1921, w archiwum Sztabu Partyzancko-Powstańczego przy Głównej Komendzie Armii URL dokumenty związane z organizacją powstania na Ukrainie w 1921 r. W archiwum O. Kowałewskiego są zgromadzone materiały dotyczące działalności Rady Republiki i Rady Ministrów URL, ukraińskich partii politycznych oraz inne dokumenty związane z funkcjonowaniem Centrum Państwowego URL na emigracji. W archiwum O. Łuckiego są przechowywane papiery związane z działalnością URP w Sejmie i Senacie RP oraz materiały dotyczące ukraińskiego ruchu spółdzielczego w Galicji pierwszej połowy XX w. W innych teczkach znajdują się m.in. papiery N. Hnatiuka, W. Sklara, O. Krasowskiego, które są również związane z działalnością SPP, Rady Ministrów i Rady Republiki URL. Dokumenty przechowywane w omawianym zasobie mają szczególną wagę dla badań nad historią ukraińskiego życia politycznego i gospodarczego, procesu literackiego oraz ruchu wydawniczego pierwszej połowy XX w. Archiwum zawiera także ważne dokumenty, które świadczą o stanie ówczesnych stosunków polsko-ukraińskich.

373 Więcej o Internacie zob. W. Kalinka, Internat ruski XX. Zmartwychwstańców we Lwowie, Lwów 1881; tegoż, Stosunek Polaków i Rusinów do Internatu Ruskiego XX. Zmartwychwstańców we Lwowie : (Sprawozdanie odczytane na walnem Zgromadzeniu Stowarzyszenia Opieki nad tymże Internatem, w marcu 1884), Lwów-Kraków 1884. 
W przeciwieństwie do materiałów z archiwum NTSz przechowywanych w kolekcji BN w Warszawie, które doczekały się szczegółowego opisu w postaci Katalogu-informatora, materiały ze zbiorów Ossolineum wciąż czekają na całościowe opracowanie, ponieważ dotychczas uwagę ukraińskich badaczy przyciągały jedynie poszczególne dokumenty i zbiory z omawianej kolekcji. Zaprezentowana w niniejszym artykule charakterystyka dokumentów z archiwum NTSz również nie jest pełna, ale przeprowadzona analiza po raz pierwszy obejmuje cały zasób, a nie pojedyncze grupy materiałów. Znaczną część dokumentów w prezentowanej publikacji również zidentyfikowano i ujawniono po raz pierwszy.

\section{Źródła}

Archiwum Naukowe Prezydium Narodowej Akademii Nauk Ukrainy (Науковий архів Президії Національної академії наук України), zespół 251, op. 1, sygn. 79.

Archiwum Państwowe we Lwowie (Державний архів Львівської області), zespół R-49, op. 1, sygn. 4.

Biblioteka Narodowa Ukrainy im. W. Wernadskiego (Національна бібліотека України ім. В. Вернадського), Archiwum, op. 1, sygn. 657.

Centralne Państwowe Archiwum Historyczne Ukrainy we Lwowie (Центральний державний історичний архів України, м. Львів), zespół. 309, op. 1, sygn. 31.

ZNiO, Dział Rękopisów, sygn. 20/53, 21/53/1-6, 22/53/1-26; 16391; 17129 II, t. 1; $70 / 88 / 1$.

\section{Opracowania}

Antonovič M., Novij dokument do istoriï powstannâ Ostrânicì. Keniğsberz'ki arhivnì materiâli do istoriï Kozaččini v peršìj polovini XVII stolittâ, „Lìtopis Červonoï Kalini” 1936, cz. 7-8, s. 35-38.

Babij Oles', [w:] Enciklopediâ ukraïnoznavstva. T. 1, red. V. Kubìjovič, Pariž-N'û-Jork 1955, s. 79.

Bieńkowska B., Działalność „Międzyrządowej Komisji Polsko-Ukraińskiej do spraw ochrony i zwrotu dóbr kultury utraconych i bezprawnie przemieszczonych podczas II wojny światowej” w zakresie bibliotek (1996-1997), „Z Badań nad Polskimi Księgozbiorami Historycznymi” 1999, z. 19, s. 153-158.

Biblioteki naukowe w Generalnym Gubernatorstwie w latach 1939-1945. Wybór dokumentów źródłowych, wybór i oprac. A. Mężyński przy współpracy H. Łaskarzewskiej, Warszawa 2003.

Bruski J.J., Petlurowcy. Centrum Państwowe Ukraińskiej Republiki Ludowej na wychodźstwie (1919-1924), Kraków 2000.

Buravčenkov A., Petriv Vsevolod Mikolajovič, [w:] Enciklopediâ istoriï Ukraïni : u 10 t. T. 8, redkol. V.A. Smolìj (golova) ta ìn., Kiïv 2011, s. 185. 
Daškevič Â., Âk nisili nezniŝenne, „Dzvìn” 1991, nr 8, s. 114-119.

Davidûk R., Volins'ke Ukraïns'ke Obêdnannâ, [w:] Enciklopediâ istorï̈ Ukraïni : u 10 t. T. 1, redkol. V.A. Smolì (golova) ta ìn., Kiïv 2003, s. 611.

Dudko F., Kviti i krov: Fil'mi ukraïns 'koï borot'bi 1919-1920 rr., Lwów 1928.

Dzûban R., Vtrati kul'turnih cinnostej z II viddilu Staatsbibliothek Lemberg v 1944 r., „Zapiski L’vìvs'koï Nacìonal'noï Naukovoï Bìblìoteki Ukraïni ìm. V. Stefanika” 2008, nr 1, s. 379-398.

Enciklopediâ „,Naukove tovaristvo imeni Ševčenka”, [online] http://encyclopedia.com.ua/ search_articles.php?id=277 [dostęp 10.05.2021].

Franko I., Towarzystwo imienia Szewczenki, „Kurjer Lwowski” 18 III 1892, nr 78, s. 2-3.

Gerasimova, Dudko Fedir, [w:] Enciklopediâ istorï Ukraïni : u 10 t. T. 2, redkol. V.A. Smolì (golova) ta ìn., Kiïv 2004, s. 490.

Gerasimova G., Gorlis-Gors 'kij Ûrij Urìjovič, [w:] Enciklopediâ istoriï Ukraïni : u 10 t. T. 2, redkol. V.A. Smolij (golova) ta ìn., Kiïv 2004, s. 167.

Gerasimova G., Gruzìn D., Kupčins'kij Roman Grigorovič, [w:] Enciklopediâ istorï Ukraïni : u 10 t. T. 5, redkol. V.A. Smolìj (golova) ta ìn., Kiïv 2009, s. 508.

Gliński P., Odpowiedź na interpelację nr 15081 w sprawie odzyskiwania dziet sztuki i zbiorów polskiego malarstwa, [online] http://www.sejm.gov.pl/sejm8.nsf/InterpelacjaTresc.xsp?key=71974A4E [dostęp 30.04.2021].

G[ruševs'kij] M., Oleksander Konis 'kij, „Hronika Ukraï ns'ko-rus'kogo NTŠ u L'vovi”' 1901, vip. 1, č. 5, s. 21-29.

Galan Wolodimir, [w:] Enciklopediâ ukrä̈noznavstva. T. 2, red. V. Kubìjovič, Pariž-N'û-Jork 1957, s. 472.

İstoriâ Nacional'noï Akademiï nauk Ukraïni: 1938-1941 : dok. i materiali, uporâd.

V.A. Kučmarenko, T.P. Papakìna, L.I. Strel's'ka ta ìn., Kiïv 2003.

Istoričnij kalendar-al'manach Červonö̈ Kalini na 1930 rik, L’vìv 1929.

Kačan V., Kabarìvs 'kij Bogdan-Adam Ìvanovič, [w:] Enciklopediâ Sučasnoï Ukraïni, [online] http://esu.com.ua/search_articles.php?id=11954 [dostęp 13.04.2021].

Kalinka W., Internat ruski XX. Zmartwychwstańców we Lwowie, Lwów 1881.

Kalinka W., Stosunek Polaków i Rusinów do Internatu Ruskiego XX. Zmartwychwstańców we Lwowie : (Sprawozdanie odczytane na walnem Zgromadzeniu Stowarzyszenia Opieki nad tymże Internatem, w marcu 1884), Lwów-Kraków 1884.

Katalog druków cyrylickich XV-XVIII wieku w zbiorach Biblioteki Narodowej, oprac. Z. Żurawińska, Z. Jaroszewicz-Pieresławcew, Warszawa 2004.

Kostruba T., Belz i Belz'ka zemlâ. Vid najdavniših časìv do 1772 roku, N'û-Jork-Toronto 1989.

Kozubel M.B., Ukraińscy Strzelcy Siczowi 1914-1920, Oświęcim 2015.

Krotofil M., Ukraińska Armia Halicka 1918-1920, Toruń 2003.

Ksenicz A., B.I. Antonycz - urodzony w Galicji, „Slavia Orientalis” 1999, t. 48, nr 1, s. 19-29.

Kučer V., Partizans'ko-Povstans'kij štab âk centr protibil'šovic'kogo ruchu oporu na Ukraïni 1921 roku, ,Voênna İstorîa” 2011, nr 1 (55), s. 37-49. 
Kušnìr V., Muzej Naukovogo tovaristva ìm. Ševčenka u L'vovì: vìd zasnuvannâ do stvorennâ peršoï zagal'nodostupnoï ekspozicï̈, „Narodoznavčì Zošiti” 2012, vip. 5, s. 824-832.

Lebedovič İ., Polevì duhovniki UGA: u 45-riččâ učasti u Vizvol'nih Zmagannâh, Vìnnìpeg 1963.

Legieć J., Armia Ukraińskiej Republiki Ludowej w wojnie polsko-ukraińsko-bolszewickiej w 1920 r., Toruń 2003.

Luc'kij O., Lepkij Lev Sil'vestrovič, [w:] Enciklopediâ istorï Ukraïni : u 10 t. T. 6, redkol. V.A. Smolij (golova) ta ìn., Kiïv 2009, s. 125.

L'vivs 'ka nacional'na naukova biblioteka Ukraïni ìmeni $V$. Stefanika: peremiŝennâ ì vtrati fondiv. T. 1: 1939-1945, L'vìv 2010.

Łużny R., Bohdan Łepki (1872-1941), [online] https://ruj.uj.edu.pl/xmlui/bitstream/handle/item/265186/luzny_bohdan_lepki_1872-1941_2000.pdf? sequence=1\&isAllowed=y [dostęp 03.05.2021].

Matwijów M., Ewakuacja zbiorów polskich ze Lwowa w 1944 r., „Rocznik Lwowski” 1995-1996, s. 31-46.

Matwijów M., Walka o lwowskie dobra kultury w latach 1945-1948, Wrocław 1996.

Mìsilo E., Ukraïns'ki cìnnostì u varšavs'komu shovisìi, [w:] Slidami pamâtì. Litopisnij kalendar. T. 1, Varšava 1996, s. 109-112.

Motornij V., Motornij A., Medovnikov O., Nevidomi ta zabutì perekladi O. Luc'kogo z čes 'koï modernoï poeziï, [w:] Muza ì čin Ostapa Luc'kogo, Kiïv 2016, s. 628-648.

Naumenko K., Balûk Ìvan, [w:] Enciklopediâ istorï Ukraïni : u 10 t. T. 1, redkol. V.A. Smolij (golova) ta ìn., Kiïv 2003, s. 177.

Naumenko K., Červona Kalina, [w:] Enciklopediâ istoriï Ukraïni : u 10 t. T. 10, redkol. V.A. Smolì (golova) ta ìn., Kiïv 2013, s. 491-492.

Naumenko K., Franko Petro İvanovič, [w:] Enciklopediâ istorï Ukrä̈ni : u 10 t. T. 10, redkol. V.A. Smolìj (golova) ta ìn., Kiïv 2013, s. 325.

Obrady Międzyrządowej Komisji Polsko-Ukraińskiej z 17 VI 2015 r., [online] http://www. mkidn.gov.pl/pages/posts/obrady-miedzyrzadowej-komisji-polsko-ukrainskiej-5577. php [dostęp 30.04.2021].

Odpowiedź podsekretarza stanu w Ministerstwie Kultury i Dziedzictwa Narodowego z upoważnienia ministra - na interpelację nr 3320 w sprawie Zaktadu Narodowego im. Ossolińskich we Lwowie, 3 VII 2006, [online] http://orka2.sejm.gov.pl/IZ5.nsf/ main/24C59E16 [dostęp 2.05.2021].

Odpowiedź podsekretarza stanu w Ministerstwie Kultury i Dziedzictwa Narodowego z upoważnienia ministra - na interpelacje nr 10390 w sprawie odzyskania polskich pamiatek kultury zagarniętych podczas II wojny światowej, 28 VII 2009, [online] http://orka2.sejm.gov.pl/IZ6.nsf/main/4057E3C6 [dostęp 2.05.2021].

O'Konnor-Vilìns'ka V., Na emigraciï: roman-hronika, L’vìv 2005.

Oles'kova İ., Peršij den' u Ġmindì, „Lìtopis Červonoï Kalini” 1939, cz. 6, s. 4-7. 
Olszański T.A., Historia Ukrainy XX wieku, Warszawa 1991.

Ostaško T., Dumin (Dumin) Osip Oleksijovič, [w:] Enciklopediâ istorï Ukraïni : u 10 t.. T. 2, redkol. V.A. Smolì (golova) ta ìn., Kiïv 2004, s. 494.

Ostaško T., O'Konnor-Vilins 'ka Valerîa Oleksandrìvna, [w:] Enciklopediâ istorï Ukraïni : u 10 t.. T. 7, redkol. V.A. Smolì (golova) ta ìn., Kiïv 2010, s. 555.

Paliênko M., Srìbnâk Ì., İnformacìjno-džerel'nij potencial arhìvnih zbìrok Nacional'nö̈ ustanowi ìmenì Ossolìns 'kih u Vroclavì z istorï̈UNR (kolekciâ 22/53), „Etnìcna İstoriâ Narodìv Êvropi” 2018, vip. 54, s. 127-140.

Pasternak Â., Nadbužanŝina: Sokal'sina, Belzčina, Radehìŝina, Kamìneččina, Holmŝina i Pidlâššâ: istorično-memuarnij zbirnik. T. 1, N'û-Jork-Pariž-Sidnej-Toronto 1986, s. 149-164.

Pavlišin O., Ukraïns'ka Nacional'na Rada v Kamâncì na Podilli (1920), [w:] Problemi vivčennâ itorï Ukraïns'kö̈revolûcï̈ 1917-1921 rokiv. Zbirnik naukovih statej. Vip. 11, Kiïv 2015, s. 118-137.

Peredrij V., Vidannâ „Červonoï Kalini” (1922-1939), L’vìv 2004.

Petrenko İ., Êlizaveta Miloradovič (1832-1890) v ukraïns'komu suspil'no-političnomu rusì, Poltava 2013.

Pilipčuk R., Zadoânnij Vasil', [w:] Enciklopedîa Sučasnoï Ukraïni, [online]

http://esu.com.ua/search_articles.php?id=13935 [dostęp 1.05.2021].

Plokhy S., Kwestia rosyjska. Jak budowano naród i imperium, przekład Ł. Witczak, Kraków 2019.

Prah B., Duhovenstvo Peremis 'koï êparhï ta Apostol's 'koï admìnistracï Lemkivŝini. T. 1, L’vìv 2015.

Romanûk M., Zubenko Ìvan Sergijovič, [w:] Enciklopediâ Sučasnoï Ukraïni, [online] http://esu.com.ua/search_articles.php?id=13935 [dostęp 4.05.2021].

Sìlec'ka O., Zasadi diâl'nostì Muzê̂ Naukovogo Tovaristva ìm. T. Ševčenka u L'vovì, „Zapiski NTSz" 2001, t. 242, s. 595-604.

Savčenko G., Drugij zimovij pohid armii UNR 1921, [w:] Enciklopediâ istoriï Ukraïni : u 10 t.. T. 2, redkol. V. A. Smolì (golova) ta ìn., Kiïv 2004.

Snìcarčuk L., Arhivni dokumenty do istoriï Ukraïns 'koï narodnoï partiï (1918-1921 rr.) $u$ viddili rukopisiv Nacional'nogo zakladu imeni Ossolìns'kih, [w:] Rukopisna ta knižkova spadŝina Ukraïni. Vip. 25, Kiïv 2020, s. 39-51.

Snìcarčuk L., Džerela do istorï̈ ukrä̈ns 'koïžurnalistiki u fondah viddilu rukopisiv Nacional'nogo zakladu ìmenì Ossolìns'kih, ,Zbìrnik Prac' Naukovo-doslìdnogo Ìnstitutu Presoznavstva" 2019, vip. 9 (27), s. 50-63.

Snìcarčuk L., Nazar Gnatûk: „Buti žrnalistami v tâžkij dla presovoï pracì čas” (19171921), „Obraz” 2017, vip. 3, s. 78-87.

Snìcarčuk L., „Nazvete našu upertu pracû korisnoû”: Vibrane z listìv Vasilâ Koroliva-Starogo do Oleksandra Kovalevs 'kogo (1919-1921 rr.), [w:] Ukrä̈ns'ka periodika : itoriâì sučasnist': materìali 11 Vseukr. nauk.-teoret. konf., L’vìv 2013, s. 581-591. 
Snìcarčuk L., ,, Organizaciâ dìjnoï i docil'noï propagandi za kordonom”: ministerstvo presi ì propagandi UNR u 1921 r., „Vìsnik L'vìvs'kogo Unìversitetu” 2015, vip. 40, s. $144-155$.

Snìcarčuk L., „,Tarnìv. Emìgraciâ. 1921 rìk”: Ŝdennikovì zapisi žurnalìsta Nazara Gnatûka, „Zbìrnik Prac’ Naukovo-doslìdnogo Ìnstitutu Presoznavstva” 2014, vip. 4, s. 559-573.

Sokal'ska (5) brigada, [w:] Enciklopediâ ukraïnoznavstva. T. 8, red. V. Kubìjovič, Pariž-N'û-Jork 1976, s. 29-38.

Sovâk P., Til'ki pro odnu knižku, [w:] Drogobic'kij knigoznaj. Vip. 1, Drogobič 2009, s. $11-13$.

Srìbnâk Ì., General V. Pavlenko vs ministra O. Kovalevs'kogo: Sproba rekonstrukcï konfliktu miž dwoma členami urâdu UNR v ekzili (za materiałami ZNiO ta CDAVO Ukraïni), „Emìnak” 2018, nr 2 (22), s. 40-45.

Srìbnâk İ., Respublika Pol'ŝa i Ukraïns'ka Narodna Respublika u borot'bì z bil'šovizmom u 1921 r. Organizacìjno-agenturna diâl'nist' Partizans 'ko-Povstans 'kogo štabu pri golovnij komandi Vijs'k UNR (za materialami ZNiO i BN), [w:] Rozpad imperiów. Kształtowanie powojennego ładu w Europie Środkowo-Wschodniej w latach 1918-1923, red. M. Gibiec, G. Ryciuk, R. Klementowski, Wrocław-Warszawa 2020, s. $492-507$.

Sribnyak I., Historia utrwalona $w$ dokumentach: źródłowe znaczenie zebrań archiwalnych Ossolineum dla rekonstrukcji działalności Rzadu Ukraińskiej Republiki Ludowej na Emigracji (na przykładzie kolekcji 22/53), „Czasopismo Zakładu Narodowego imienia Ossolińskich” 2018, z. 29, s. 155-173.

Stasenko V., Bačins'kij Leonìd Vasil'ovič, [w:] Enciklopediâ sučasnoï Ukrä̈ni : u 30 t. T. 2, Kiïv 2003, s. 335-336.

Strìlec' N., Vertep naših dnìv - gumorističnij barometr galic'kogo suspil'stva, [online] http://www.lepkiy.te.ua/index.php/uk/statti-ta-uchast-u-konferentsiiakh [dostęp 25.04.2021].

Strilec'ka Golgofa : sproba antologii, uporâdnik, avtor vstupnoï stattì ì primìtok T.Û. Saliga, L'vìv 1992.

Strilec'kij Kalendar-Al'manah Presovoï Kvatiri U. S. V. v polì na zvičajnij rìk 1917, L'vìv 1917.

Studins'kij K., Do istorï̈ vzaêmin Galičini z Ukraïnô̂ v rokah 1860-1873, [w:] Ukraïna. Naukowij dvomisâčnik ukrä̈noznavstva. Kn. 2, Kï̈v 1928.

Szumiło M., Ukraińska reprezentacja parlamentarna w Sejmie i Senacie RP (1928-1939), Warszawa 2007.

Suško R., Hto vbiv polkovnika Otmarštajna, Praha 1933.

Svarnik G., Arhìvni ta rukopisni zbirki Naukovogo tovaristva ìm. Ševčenka v Nacional'nìj bibliotecì u Varšavì : Katalog-informator, Varšava-L'vìv-N'û-Jork 2005.

Svarnik G., Či povernut'sâ v Ukraïnu arhivi Naukovogo tovaristva imeni Ševčenka?, „Dzerkalo Tižnâ” 22 X 2016, nr 38/39, [online] http://gazeta.dt.ua/article/print/perso- 
nalities/chi-povernutsya-v-ukrayinu-arhivi-naukovogotovaristva-imeni-shevchenka-_. html [dostęp 10.05.2021].

Škarbûk P., ,Vidrodžennâ”, [w:] Enciklopediâ istorï̈ Ukraïni : u 10 t. T. 1, redkol. V.A Smolij (golova) ta ìn., Kiïv 2003, s. 533.

Tarnów - siedziba władz Ukraińskiej Republiki Ludowej. Prezentacja archiwaliów ukraińskich ze zbiorów Zakładu Narodowego im. Ossolińskich (wystawa), oprac. A. Warżel, O. Medownikow, I. Lipko, Tarnów 2003.

Tel'vak V.V., Tel'vak V.P., ,, Strašenno važo zberìgati v se vremâ lute živij partìjnij oseredok": listi Mihajla Gruševs 'kogo z biblioteki Nacional'nogo ìnstitutu ìm. Ossolins 'kih, „Ukraïns'kij İstoričnij Žurnal” 2019, nr 3, s. 166-182.

Tinčenko Â., Oficers'kij korpus Armï Ukrä̈ns'koï Narodnoï Respubliki (1917-1921). Kn. 1, Kiïv 2007; Kn. 2, Kiïv 2011.

Vasylenko V., Pidgotovka antibil'šovic 'kogo povstannâ v Ukraïnì u 1921 r. (za dokumentami GDA Službi bezpeki Ukraïni), „Z arhìvìv VUČK - GPU - NKVD - KGB” 2008, nr 1/2 (30/31), s. 139-197.

Vertep naših dniv, „Svoboda” 21 VI 1930, nr 143, s. 3.

Vertep naših dniv (viïmok z III-oï diï), „Ziz” 1 VI 1928, nr 11, s. 3-4.

Vinničuk Û., Rozìpâta muza, L’vìv 2011.

Wrzosek S., Związek Rewizyjny Spółdzielni Ukraińskich we Lwowie, [w:] Encyklopedia historii gospodarczej Polski do 1945. T. 2, Warszawa 1981, s. 564.

Zadoânnij V., Naddnistrâncì v Taraŝans 'komu povìti, „Lìtopis Červonoï Kalini” 1932, cz. 2, s. 6-7.

Zadoânnij V., Naddnistrâncì v Taraŝans'komu povìtì : urivok z priladženoï do druku knižki: , Taraŝans 'kij povit v borot'bì za samostìnnist' Ukraïni”, „Nauka ì Suspìl'stvo” 2020, nr 1-2, s. 45-46.

Zolotì Vorota. İstoriâ Sičovih Stril' cìv, L'vìv 1937.

Zubenko İ., Naši licarì j mučeniki. Č. 1, Kališ 1922. 
